\title{
FALSEDAD DOCUMENTAL COMO DELITO DE ENGAÑO
}

\author{
FORGERY AS CRIME OF DECEIT
}

\author{
Luis Emilio Rojas Aguirre*
}

\begin{abstract}
RESUMEN: Como los tipos contemplados en los artículos 193, 194 y 197 del Código penal resultan aplicables cuando la falsedad recae en un documento público o en uno privado, la doctrina tradicional analiza directamente el concepto de documento público y de documento privado. Al proceder de este modo, soslaya que los tipos de falsedad comparten una misma forma de descripción de la conducta prohibida, con la frase "cometer falsedad en un documento". El presente trabajo intenta solamente esclarecer el significado de esta frase mediante la pregunta ¿qué significa cometer falsedad en un documento? No es posible responder a esta pregunta sin aproximarse al concepto de documento, el cual constituye entonces objeto principal de las siguientes reflexiones. La doctrina del delito de falsedad documental se torna así en una dogmática del documento, a la cual se pretende contribuir desde una perspectiva funcionalista, esto es, que analiza el concepto de documento a partir del esclarecimiento previo de la función que este cumple en el tráfico jurídico.
\end{abstract}

Palabras clave: Falsedad documental, concepto de documento, injusto del delito.

ABSTRACT: Criminal offences referred in articles 193, 194 and 197 of Criminal Code apply when forgery is committed on a public or private document. This fact explains why legal scholars study forgery analyzing the concept of both kinds of documents separately. But this approach forgets that those offences describe the criminal conduct in the same way, that is, "to commit forgery in a document". This work is an attempt to ascertain the sense of this sentence through the question what does committing forgery in a document means? I think it is impossible to answer this question without an understanding of the concept of document, which is the main focus of the reflections that follows. The theory of the forgery becomes, thus, a theory of the document. In this sense, the paper is a contribution to the later from a functionalist approach, that is, one that analyzes the concept of document, studying previously the function it has in the legal environment.

Key words: Forgery, document, unlawfulness.

\section{INTRODUCCIÓN}

Por qué debe responder penalmente un sujeto que simplemente crea un documento falso, es una de las preguntas que más han inquietado a la ciencia del Derecho pe-

\footnotetext{
* Profesor de Derecho penal, Universidad Alberto Hurtado, correo electrónico: lurojas@uahurtado.cl. Licenciado en Ciencias Jurídicas y Sociales, Universidad de Chile. LL.M. y Doctor en Derecho Albert-LudwigsUniversität Freiburg. Este artículo ha sido escrito en el marco del proyecto Fondecyt N. 1110512 "Falsedades documentales: entre autenticidad y verdad. Hacia una revisión del sistema de delitos de los artículos 193 a 198 del Código penal", en el cual el autor participa como investigador responsable; agradecimientos al asistente del Departamento de Derecho penal y ayudante de investigación Mg. Rodrigo Vergara; asimismo, el autor extiende sus agradecimientos a los participantes en la discusión del borrador del presente trabajo en un seminario realizado el 15 de mayo de 2013 y, en especial, al Prof. Dr. Héctor Hernández por sus observaciones.
} 
nal. En nuestro contexto, ya en 1944 Cousiño declaraba este ámbito de la parte especial

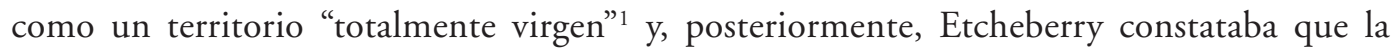
vacilación y la incertidumbre son probablemente mayores que en "cualquiera otra materia jurídico-penal" 2 . El origen de estas incertezas radica, por una parte, en la técnica legislativa poco diferenciada del Código penal, que tuvo como modelo al Código penal español de 1848/1850, el cual a su vez siguió la sistemática del Code pénal francés de $1810^{3}$. De acuerdo con esta sistemática, la regulación penal de la falsedad documental parte con el tipo del art. 193, ubicado en el título IV "de los crímenes y simples delitos contra la fe pública, de la falsificación, del falso testimonio y del perjurio", en cuyo encabezado se alude al "empleado público que, abusando de su oficio, cometiere falsedad" y luego describe distintas modalidades de comisión. Especialmente problemática es la técnica legislativa adoptada en el tipo del art. 194, que castiga al "particular que cometiere en documento público o auténtico alguna de las falsedades designadas en el artículo anterior”. Y no menos problemática es la descripción de la conducta punible que consagra el tipo del art. 197 sobre falsificación de instrumento privado, al señalar "el que, con perjuicio de tercero, cometiere en instrumento privado alguna de las falsedades designadas en el artículo 193”4 .

Por otra parte, esta técnica legislativa poco diferenciada ha suscitado una lectura más bien enrevesada de la doctrina. Para justificar racionalmente la norma que castiga al empleado público que comete falsedad en documento público (art. $193 \mathrm{CP}$ ), la doctrina sale en busca de un bien jurídico y recurre a la mención que el epígrafe del título IV hace a la "fe pública"5. El injusto del delito derivaría de un atentado a la fe pública, además cometido por un empleado público, por lo que se trataría de un delito especial contra la función pública ${ }^{6}$. En el caso del tipo del art. 194, se trataría también de un atentado a la fe pública, pero cometido por un particular, no obligado especialmente a su protección, por lo que se trataría de un delito común 7 . Y el tipo del art. 197, no obstante estar ubicado en el mismo título IV de los delitos contra la fe pública, consistiría en un delito patrimonial, pues, para su configuración, a diferencia de los anteriores, la ley penal exige expresamente un "perjuicio a tercero".

Esta forma de aproximarse a la materia es efecto de lo que puede denominarse un "doble embrujo". De un lado, del efecto que provoca la alusión del título IV a la fe pública, reforzado por la calidad de empleado público que debe tener el sujeto activo para realizar el tipo del art. 193, además del abuso de su oficio. Lo protegido por la norma sería un bien

\footnotetext{
1 Cousiño (1944) p. 6.

2 Etcheberry (1961a) p. 33.

Rojas (2012) pp. 556 y ss.

4 Véase la discusión entre Cousiño y OrTIZ, en Cousiño (1944) pp. 207 y ss.; recientemente, sobre esta discusión VARGAS (2011) pp. 194 y ss.

5 Introducida en la sesión N. 170, de 8 de octubre de 1873, de la Comisión redactora del Código penal, a propuesta de Gandarillas ACTAS (1873) p. 307: "porque de todas estas materias se trata en él”; contra Quinteros (1959); ETCHEBERry (2002) N. 438 pp. 255 y ss.

${ }^{6}$ Véase Etcheberry (1961a) p. 56; en la doctrina española, respecto del tipo equivalente, Villacampa (1999) p. 96; Bacigalupo (2007) p. 14 y ss., 103 y ss.

7 Bacigalupo (2007) p. 103 y ss., respecto del tipo equivalente en el CP español.

8 Etcheberry (1961a) p. 63.
} 
jurídico colectivo. De otro lado, la exigencia de perjuicio en el delito de falsedad en documento privado se asocia de forma poco reflexiva y prácticamente automática con delito patrimonial, por lo que la norma protegería al patrimonio ${ }^{9}$. Esta aproximación tradicional a la materia lleva a extremar las diferencias entre los tipos mencionados hasta comprender el injusto de cada uno de modo esencialmente distinto. Pierde de vista la existencia de un injusto básico común que surge de la misma forma de describir el núcleo de la conducta prohibida en los tipos penales arriba citados: cometer falsedad en documento, público o privado.

Metodológicamente, la aproximación tradicional de la doctrina opera de forma deductiva, esto es, construye una premisa en un nivel muy elevado de abstracción y generalidad, como es la búsqueda y definición de un bien jurídico, y luego propone una reconstrucción más o menos razonable de los elementos del tipo, en todo caso, fundamentalmente consistente con la premisa que se estima correcta. Esta forma más bien sofisticada de aproximarse a la materia permite a la doctrina evitar una pregunta que le resulta incómoda, porque le obliga a entrar en consideraciones que la propia doctrina tilda de "metafísicas"10, como es la pregunta por la falsedad. Le resulta incómoda simplemente porque es una empresa inconducente tratar de responder a esta pregunta sin reflexionar sobre el concepto de verdad. La falsedad no puede comprenderse sin la verdad.

A continuación, se propone una aproximación metodológica distinta, menos sofisticada que la tradicional. Se trata de suspender por un momento la discusión más bien abstracta sobre el bien jurídico protegido y bajar al nivel menos elevado del texto de la ley penal. Detenerse un momento y volver a realizar el simple ejercicio de leer el texto de la ley penal que describe el núcleo de la conducta punible con la frase "cometer falsedad en un documento". E intentar responder a la pregunta siguiente: ¿qué significa cometer falsedad en un documento?, ¿qué es falsedad documental?

\section{APROXIMACIÓN AL CONCEPTO DE DOCUMENTO}

En principio, falsedad documental es lo contrario de un documento verdadero. Cometer falsedad es, entonces, crear un documento falso, un no documento. Esta definición conduce a una tautología, de la cual solo puede escaparse en la medida en que se expliciten los elementos que deben concurrir para estar en presencia de un documento. La definición de falsedad documental conduce, entonces, a la necesidad de definir su contrario que es el documento, es decir, aproximarse a un concepto de documento.

\subsection{FunCión Del DOCUMENTO: PRESUPUESTO DE EXISTENCIA DEL ORdENAMIENTO JURÍDICO}

Se habla de documento y no de instrumento, porque la palabra "instrumento" denota solo un aspecto del concepto, cual es, el de ser un medio de prueba. En la sesión N.

\footnotetext{
9 Así ya en Banco Central de Chile contra Becerra (1947), recientemente, Contra Arzola (2010), en que Corte Suprema vincula la exigencia de perjuicio con el bien jurídico protegido "propiedad" (considerando $4^{\circ}$ ).

10 Un ejemplo de esta aproximación metodológica, Rodríguez Collao y Vera (2004) p. 113 y ss.; en la doctrina española, Boldova (2000) pp. 4 y ss.; Villacampa (1999) p. 322 y ss., renuncia al concepto prepositivo de falsedad, esto es, previo al análisis de los tipos penales de falsedad documental en el CP español.
} 
41 de la Comisión redactora del Código penal chileno, de 2 de junio de 1871, se dejó constancia de la preferencia por ajustar las denominaciones de los epígrafes de este grupo de delitos a la nomenclatura del Código civil ${ }^{11}$. Sin embargo, por razones no explicitadas, en la sesión N. 43, de 9 de junio de 1871, quedó constancia de la modificación solo del párrafo 5 "De la falsificación de instrumentos privados", lo cual explica que el párrafo 4 "De la falsificación de documentos públicos o auténticos" siga utilizando la palabra "documento". Este ajuste parcial del texto de la ley penal permite a la doctrina usar indistintamente la palabra documento o instrumento ${ }^{12}$. Sin embargo, no le autoriza a soslayar la voluntad del legislador penal de someter la interpretación de las palabras "documento público" o "instrumento privado" a las definiciones y, en general, a la regulación de los instrumentos públicos y privados contenida en la legislación civil ${ }^{13}$. En este sentido, uno de los primeros comentaristas del Código penal define instrumento privado como "todo aquel que sirve para probar una obligación o su estincion, o sea, todo aquel que sirve como fundamento de una acción o de una escepcion" ${ }^{14}$. En efecto, el Código civil define y regula los instrumentos públicos y privados en el título XXI sobre la "prueba de las obligaciones" (arts. 1698 y ss.), junto a otras formas de probar las obligaciones o su extinción, como las presunciones, la confesión, etc. Sin embargo, no regula la forma ni la oportunidad en que estas pruebas pueden ser usadas en juicio. Las reglas de producción de pruebas en juicio, incluida la forma de usar los documentos como medios de prueba, se encuentran contempladas en los arts. 341 y ss. del Código de procedimiento civil. Esta constatación permite deducir que el alcance de la regulación de los documentos contenida en el Código civil no se agota en el uso de los mismos como medios de prueba en juicio, sino que abarca en general la función probatoria que el documento cumple en el tráfico jurídico, esto es, la de probar la existencia de actos jurídicos (v.gr.: art. 1701 inc. $1^{\circ}$ CC: “actos y contratos") $)^{15}$.

Sin embargo, la existencia de un acto jurídico también puede probarse mediante la declaración oral de un testigo. La pregunta que surge, entonces, es por el rendimiento propio del documento en comparación con la declaración oral. O, planteado en la nomenclatura de la regulación jurídico-civil, ¿por qué la legislación civil prefiere que actos jurídicos de cierta importancia "consten por escrito" y no dependan de la "prueba de testigos"? (v.gr.: art. 1709 CC). Porque la fijación por escrito de una declaración cumple una función que el testimonio oral no puede rendir o solo hacerlo de modo deficiente. Por ejemplo, un deudor se muestra dispuesto al pago de su obligación frente a su acreedor, en la medida en que este le extienda un recibo del pago. En esa situación, al deudor no le interesa que el acreedor

\footnotetext{
11 ACTAS (1873) p. 84.

12 Etcheberry (1961b) pp. 225 y ss.

13 Cousiño (1944) pp. 15 y ss.; en contra, EtCheberry (2002) N. 439 pp. 259 y ss., con cita de jurisprudencia que subscribe un concepto de documento público más amplio que el recogido en el art. 1699 CC, en base a un análisis histórico de las reglas civiles que contienen esa definición y, además, la diversa naturaleza y objetivo de las disposiciones penales, que incluyen una mención a los documentos oficiales, categoría no utilizada en el Código Civil.

14 Fernández (1899) p. 328.

15 En este sentido, ya contra Duque (1930); subrayan "la estrecha conexión que existe entre la falsificación documentaria y el régimen de la prueba”, contra Toriello (1950); contra Matus (1950).
} 
declare oralmente haber recibido el pago, sino que este pago "conste por escrito". El otorgamiento del recibo por parte del acreedor motiva el pago del deudor. En ese momento, el documento no cumple la función de probar la extinción de la obligación, hecho que por lo demás sucede frente a los ojos del deudor y del acreedor. Actualmente, el documento no prueba nada, sino que motiva la conducta jurídicamente relevante del receptor ${ }^{16}$. Aunque potencialmente, en el evento de producirse un conflicto, porque por ejemplo el acreedor niega haber recibido el pago y demanda al deudor, el documento puede servir de medio de prueba en un proceso y cumplir la función de probar la extinción de la obligación. Otro ejemplo: un sujeto ofrece venderle su auto a otro, con el cual llegan a un acuerdo respecto del precio y deciden verterlo por escrito. En esta situación, la fijación por escrito tampoco cumple la función de probar la existencia del contrato. Ni el vendedor ni el comprador tienen una duda que pueda despejarse mediante el documento. Actualmente, este no prueba nada. En ese momento, el documento, en el cual se escritura el contrato, más bien forma parte de este.

Ambos ejemplos son distintos, porque el contenido del documento otorgado es diferente. En el primer ejemplo, se trata de un hecho que produce un efecto jurídico, como es el pago de una obligación por parte de un deudor. El documento extendido por el acreedor, el recibo del pago, constituye un testimonio escrito del hecho realizado por otro sujeto, como es el deudor, da cuenta de un acto jurídicamente relevante realizado por este último. En el segundo ejemplo, el contrato escriturado de compraventa, es un documento que contiene un acto jurídico bilateral, del cual nacen derechos y obligaciones para ambas partes que concurren en el otorgamiento del documento. En este sentido, un magistrado chileno, en la década del 50, señalaba que "todo instrumento para ser tal, debe tener un contenido que no es otro que la declaración, manifestación o testimonio (capaz de producir efectos jurídicos) del autor" ${ }^{\prime 7}$. Según esta definición, si el documento contiene una manifestación de voluntad, se trata de un documento dispositivo. Si en cambio el documento contiene el testimonio sobre un hecho apto para producir efectos jurídicos, se denomina documento testimonial. En el mismo sentido, una sentencia de la Corte de Apelaciones de Santiago, del 10 de noviembre de 1955, define la falsificación de instrumento privado como "la adulteración de un escrito del cual por sí mismo se derive una obligación de un tercero o su extinción y que a su vez constituya por lo menos un principio de prueba por escrito en su contra (...)"18. Un escrito del cual "por sí mismo" se deriva una obligación o su extinción es lo que la doctrina alemana llama, en base a una distinción que hacen los $\$ \$ 415$ ss. de la Zivilprozessordnung (ZPO: ordenanza procesal civil), un documento dispositivo, porque forma parte del negocio jurídico. El otorgante y el receptor del documento están interesados directamente en los efectos jurídicos que produce el acto contenido en el mismo y solo mediatamente en la prueba de la realización del acto. En cambio, el documento testimonial solo contiene la declaración sobre un hecho jurídicamente relevante, por ejemplo, un cer-

\footnotetext{
${ }_{16}$ Ejemplo y argumentación de SAMSON (1968) p. 110.

17 Peña (1954) p. 54.

${ }_{18}$ Contra Olguín (1955), lo que no concurre en el caso resuelto, pues el "reo" había confeccionado simples planillas "desde que por sí misma, no emanaba de ellas ninguna obligación para el ofendido quién a su arbitrio podía aceptarlas o desecharlas (...)”.
} 
tificado de defunción emitido por un médico ${ }^{19}$. Aquí el otorgante y el receptor del documento están interesados directamente en la prueba del hecho y solo mediatamente en las consecuencias jurídicas que se derivan de este ${ }^{20}$.

Ambos tipos de documentos, en el momento en que se otorgan, cumplen una función constitutiva en el tráfico jurídico, cual es, que motivan la realización de conductas jurídicamente relevantes por parte del receptor del documento. En el ejemplo del recibo extendido por el acreedor, el pago realizado por el deudor que recibe el documento. En el ejemplo de la compraventa del auto, la escrituración del contrato por ambas partes, condiciona recíprocamente la concurrencia de la voluntad del comprador y del vendedor en la creación de los derechos y obligaciones que derivan del contrato. Son estas conductas las que, en ejercicio de la libertad que el ordenamiento jurídico le concede a los sujetos, configuran relaciones jurídicas y constituyen también, en el marco de la autonomía de la voluntad, el ordenamiento jurídico mismo ${ }^{21}$. También es posible constituir relaciones jurídicas mediante una declaración oral, por ejemplo, ofrecer la venta de una cosa cuyo valor es inferior a 2 UTM (art. 1709 CC). Pero, la desventaja de aquella en comparación con el otorgamiento de un documento, radica en que, por una parte, en el momento de emitir la declaración, el sujeto fácticamente puede desdecirse de ella ("las palabras se las lleva el viento"). Esto no lo puede hacer si fija su declaración en un documento, pues entonces el receptor del mismo puede enrostrarle siempre su inveracidad ${ }^{22}$. Y, por otra parte, aun cuando el sujeto no se desdiga, en el evento futuro de un conflicto, la prueba de la existencia del acto jurídico queda supeditada a la voluntad del declarante o del receptor de la oferta verbal o,

19 Un certificado de defunción emitido por un médico da cuenta de un hecho cierto que produce consecuencias jurídicas, según contra Fernández (2008).

20 SAmson (1968) pp. 109 y ss.; Rheineck (1979) pp. 131 y ss.; Steinmetz (1991) p. 132 nota 217, critica y relativiza esta distinción, pues existen formas intermedias que pueden contener tanto declaraciones dispositivas como testimoniales; sin embargo, esto último no constituye un problema, por ejemplo, en Bavestrello con Dall' Orso (1936), se trataba de un mutuo que había sido vertido en una escritura pública ante Notario, en que la mutuaria luego había muerto y el mutuante demandó civilmente al heredero de aquella, este último probó la falsedad de la escritura pública; de haber sido verdadera la escritura pública, esta habría sido un documento dispositivo otorgado por las partes, que contenía un mutuo de dinero, y, al mismo tiempo de su extensión, habría sido un documento testimonial otorgado por el Notario, en cumplimiento del "rol esencial, por no decir el único del Notario, es prestar autoridad al instrumento que ante él se otorga, revistiéndolo de la fe pública de que es depositario, al atestiguar que ante él comparecieron las partes (...)" (considerado 20\%); en este sentido, JAKOBS (2000) p. 49 y s., señala que al documentarse la declaración de la parte ante el Notario, se agrega un "plus" que así es considerado en el tráfico jurídico, que no consiste en una mera ficción, sino que mediante la fijación de su testimonio se vuelve al mismo tiempo escribiente del declarante.

21 Las simples testificaciones escritas (privadas) sin efectos jurídicos "son cifras sobre el estado (presunto) del mundo exterior y por eso a proteger del mismo modo como se protege este mundo", JAKOBS (2000) p. 52 y ss., ejemplo, exámenes escritos que dan cuenta del rendimiento de estudiantes (nota 88); se trata, según JAKOBS, de meras evidencias materiales, no de documentos (p. 54 y ss.); Puppe (2013) núm. marg. 7, le critica ir demasiado lejos al quitarle carácter documental a tales testificaciones privadas; JAKOBS (2007) p. 232, responde: simples testificaciones no son medios de prueba originarios, sino derivativos, porque no contienen aquello a probar, sino que solo remiten a este, en cambio, documentos corporeízan efectos jurídicos, en caso de ser auténticos, son fuentes de estos efectos; Puppe (2013), núm. marg. 7, retruca: esto es correcto, pero no es nuevo, afirmaciones, que de ninguna manera pueden configurar efectos jurídicos, pertenecen a la vida privada y expresiones privadas no son documentos.

22 SAMSON (1968) p. 111 y ss. 
en el mejor de los casos, de un tercero que la escuchó. En cambio, la ventaja comparativa del documento radica en que su uso en el ámbito extraprocesal o en el proceso es independiente de la voluntad de los interesados ${ }^{23}$. Por eso, en el tráfico jurídico, se prefiere, al menos respecto de negocios jurídicos de cierta monta, documentar declaraciones de voluntad -documentos dispositivos- o declaraciones testimoniales sobre la ocurrencia de un hecho jurídicamente relevante -documentos testimoniales-, antes que dejarlas abandonadas a la siempre perecedera palabra oral ${ }^{24}$.

\section{Cuadro RESUMEN:}

\begin{tabular}{|l|l|l|}
\hline $\begin{array}{l}\text { Función que cumple el } \\
\text { documento en el tráfico } \\
\text { jurídico }{ }^{25} \text { se otorga un } \\
\text { documento para producir } \\
\text { efectos en otro. } \rightarrow\end{array}$ & $\begin{array}{l}\text { En el tráfico jurídico como } \\
\text { en el } \\
\text { vida jurídica. } \\
\downarrow\end{array}$ & $\begin{array}{l}\text { En el ámbito procesal como } \\
\text { una parte del tráfico jurídico: } \\
\text { tráfico probatorio }{ }^{26} . \\
\downarrow\end{array}$ \\
\hline $\begin{array}{l}\text { Documento dispositivo parte del acto jurídico; } \\
\text { en el presente, no prueba } \\
\text { nada; efecto buscado es una } \\
\text { conducta jurídicamente rele- } \\
\text { vante de otro (receptor). }\end{array}$ & $\begin{array}{l}\text { Medio de prueba de la reali- } \\
\text { zación en el pasado de un } \\
\text { acto jurídico; efecto buscado } \\
\text { es intelectual, generar en el } \\
\text { otro (receptor juez o parte) } \\
\text { la representación verdadera } \\
\text { de la realización del acto jurí- } \\
\text { dico. }\end{array}$ \\
\hline
\end{tabular}

23 SAmson (1968) p. 116 y ss.; Luhmann (1993) p. 246 y ss.: la escritura facilita el recurso a los contenidos de sentido, dificulta el (en sí beneficioso) olvido. La escritura vuelve la comunicación independiente del momento de su emisión y así ampliamente independiente también de las intenciones de los emisores. Si se recurre a esa intención o no, se vuelve una pregunta de la interpretación” (traducción libre).

24 Luhmann (1993) p. 254: Tiene que ver con la anticipación de frustraciones, que primeramente dan el motivo para comunicar expectativas en estilo normativo. Así se vuelve actual una diferencia temporal, que debe superarse. Una información que declara que una expectativa determinada se corresponde con el Derecho o no se corresponde, debe servir dos veces (o repetidamente) como información: en el momento de su proyección y siempre que se vuelve actual una acción que la frustra"; p. 255: "en el sistema autopoiético dinámicamente estabilizado de la comunicación social, no existe un interés en la estabilidad del sentido en sí. El problema radica en la anticipación de un interés renovado en la misma información y no simplemente en que lo duradero es mejor que lo perecedero [...] (destacado en original). La incerteza de si expectativas normativas también más tarde, si no se satisfacen o se piensa en ello, van a ser reconocidas como Derecho, no desaparece; solo se transforma. La escritura sustituye solo una nueva diferencia, aquella entre signo y sentido. Tomado en el contexto de la comunicación plena de sentido, el texto escrito no puede más que organizar y posibilitar las remisiones al sentido posible. Y también esto es un movimiento doble de la reducción y producción de complejidad, de la producción de complejidad mediante reducción. En el medio sentido, la diferencia de medio y forma se duplica. Aparecen nuevas diferenciaciones, en las cuales el texto ocupa una lado y vuelve el otro accesible, respectivamente: la diferenciación de texto e interpretación, la diferenciación de texto y contexto, la diferenciación de sentido explícito y buscado" (traducción libre; destacado agregado).

25 ¿Qué es tráfico jurídico? La actualización de reglas del ordenamiento jurídico.

26 El proceso no se encuentra fuera del tráfico jurídico, es parte de la vida jurídica (!), solo que se trata de aquella parte de la vida jurídica que se desarrolla conforme a las reglas formales del procedimiento. 


\begin{tabular}{|c|c|c|}
\hline $\begin{array}{l}\text { Documento testimonial } \\
\rightarrow\end{array}$ & $\begin{array}{l}\text { Expresa la observación de } \\
\text { una circunstancia fáctica ju- } \\
\text { rídicamente relevante; en el } \\
\text { presente, no prueba nada; } \\
\text { efecto buscado es una con- } \\
\text { ducta jurídicamente relevante } \\
\text { de otro (receptor). }\end{array}$ & $\begin{array}{l}\text { Medio de prueba de la obser- } \\
\text { vación de un hecho jurídica- } \\
\text { mente relevante realizada en } \\
\text { el pasado; efecto buscado es } \\
\text { intelectual, generar en el otro } \\
\text { (receptor juez o parte) la re- } \\
\text { presentación verdadera de la } \\
\text { observación y, mediatamente, } \\
\text { del hecho jurídicamente rele- } \\
\text { vante. }\end{array}$ \\
\hline $\begin{array}{l}\downarrow \\
\text { Paralelo con rendimiento } \\
\text { de declaración oral } \rightarrow\end{array}$ & $\begin{array}{l}\text { Restringido a actos de dispo- } \\
\text { sición de inferior monta } \\
\text { (art. 1709 CC: } 2 \text { UTM) o } \\
\text { derechamente indiferente: } \\
\text { "las palabras se las lleva el } \\
\text { viento". }\end{array}$ & $\begin{array}{l}\text { El testimonio es la "reina de } \\
\text { las pruebas" por la inmedia- } \\
\text { tez. }\end{array}$ \\
\hline
\end{tabular}

\subsection{DOCUMENTO Y SIgNO: UNA DIGRESIÓN LINGÜístiCA EN TORNO A LA EXIGENCIA DE} ESCRITURA

Lo anterior muestra que la función que cumple el documento en el tráfico jurídico no se agota en la de ser un medio de prueba ${ }^{27}$. Esta última función, por cierto que también la cumple, especialmente en el marco de un proceso y conforme a las reglas de procedimiento sobre incorporación de prueba documental en juicio, cuando un conflicto se vuelve actual. Pero, en el momento del otorgamiento de un documento, testimonial o dispositivo, este cumple una función constitutiva en el tráfico jurídico, aun sin probar nada. La pregunta que surge ahora, es si esta función que cumple el documento en el tráfico jurídico y probatorio, solo puede prestarla en el medio de la escritura o también mediante la fijación de signos no lingüísticos. Esta pregunta conduce a la clásica discusión sobre la exigencia de escritura para el concepto de documento.

\footnotetext{
27 En la doctrina nacional, en este sentido ya Etcheberry (1961a) p. 55, se aparta de la tesis de Binding: "Si bien uno de los efectos, y tal vez el más general, de los documentos es el de servir de prueba, su proyección jurídica no se limita a ello"; lo protegido por las normas sobre falsedad documental (con exclusión de documentos privados) y también de falsificación de moneda, son "ciertos efectos jurídicos de obligatoriedad general” (p. 57; destacado original), a falta de mejor denominación "el tráfico jurídico" (p. 60; destacado original), pero, con razón, no la "seguridad del tráfico jurídico", siguiendo en este punto la crítica de Frank (p. 61); en igual sentido, ETCHEBERRY (1997) p. 135; sin embargo, en esta tesis no se comprende por qué resultan excluidos los documentos privados, esto es, documentos que fijan relaciones sometidas a la regulación del Derecho privado, por ej. una escritura privada de compraventa de un vehículo, desde ya el contrato produce efectos jurídicos entre las partes, pero, además, la escrituración del mismo debe ser observada por el Notario, luego por el Registro Civil al inscribirse la "transferencia" y, en el evento de un proceso, puede servir de prueba ante un Tribunal; en este sentido, la determinación para el tráfico jurídico, que FranK (1908) p. 450, propone en lugar de la determinación probatoria (“documento es una declaración corporeizada y determinada para el tráfico jurídico”), se refiere al tráfico regulado por el Derecho privado, a tal punto que Frank debe advertir expresamente que el tráfico jurídico no se restringe al jurídico-privado ("debe advertirse expresamente que el tráfico jurídico de ningún modo necesita ser jurídico-privado”), por ende, abarca también las relaciones ceñidas al Derecho público.
} 
Fue Karl Binding el primero en encender esta discusión, al apartarse categóricamente de una línea jurisprudencial del Tribunal supremo del Reich ("Reichsgericht": RG) que tendía a definir documento como un objeto sin vida producto de la obra humana, apto para la prueba de un hecho ${ }^{28}$. Esta línea jurisprudencial que, entonces, sostiene una teoría del objeto en la dogmática del documento, plantea un problema de delimitación con las evidencias materiales ("Augenscheinsobjekte"). Puesto que si el documento es un objeto apto para probar un hecho, entonces, el pañuelo que deja Jago para atizar los celos de Otelo también es un documento ${ }^{29}$. Frente a este problema, el Reichsgericht aclara primeramente que no todo objeto puede ser documento, pues "entre los objetos sin vida, no existe ninguno en la tierra que bajo circunstancias no sea apto para probar alguna circunstancia fáctica, que no pueda revestir el atributo que sería común con los documentos de la capacidad probatoria o de la aptitud para la prueba" ${ }^{30}$. Para que un objeto sea calificado de documento, debe contener una "expresión de pensamiento" ${ }^{1}$. Conforme a este criterio, el RG diferencia entre signos probatorios y meras señales. Los primeros, como por ej. una patente de auto, una marca comercial, pertenecen al concepto de documento, en cambio, en las segundas, como por ej. una mancha de sangre, una huella, se trata de evidencias materiales ${ }^{32}$. Es esta

28 Aparentemente, bajo la influencia de Merkel (1889) $\$ 140$ N. 2: "Documentos son objetos con fuerza probatoria en el tráfico o en el proceso para circunstancias fácticas jurídicamente relevantes, basada en una norma general o en virtud de una determinación decisiva en el caso concreto. El $\$ 267$ distingue entre documentos privados y públicos. Estos últimos son documentos provenientes de una persona llamada estatalmente a certificar hechos en forma legal y dentro de su competencia" (p. 359); en contra Binding (1904) p. 180: "Solo aquel que nunca ha reflexionado sobre la profunda oposición entre lenguaje y símbolo y nunca sobre la diferencia de cómo y por qué prueban, puede permitirse, frente a la historia del Derecho alemán, que tan claramente transmite la concepción del pasado, y frente al Derecho vigente, que sujeto a esta concepción también actualmente todavía separa estrictamente la falsedad documental de aquella de la moneda, del signo fronterizo y de nivel de agua, de la marca comercial, que asimismo no confunde de ningún modo la falsedad de medidas con la falsedad documental, incluir todos los signos probatorios entre los documentos y de este modo revelar como provocar una gran confusión" (destacado agregado).

29 Ejemplo de Kienapfel (1967) p. 70 y s., quien dedicó su escrito de habilitación como profesor al análisis de toda la jurisprudencia del RG a lo largo de sus casi 8 décadas de existencia hasta la creación del Tribunal Supremo Federal (BGH), llegando a la conclusión de que no había ningún intersticio de esta materia que no hubiese sido aclarado por el RG (prefacio).

30 RGSt. 17, 103 (105); en la doctrina nacional, ETCHeberRy (1961b) p. 227, suscribe una teoría del objeto, pero, consistente con su crítica a la tesis de Binding, sin exigir el atributo de la aptitud probatoria (p. 225 y ss.).

31 RGSt. 17, 103 (106): "un botón caído, una mancha de sangre, una cadáver humano son probablemente medios de prueba importantes en relación a ciertos hechos, por tanto, en gran medida aptos para la prueba, pero no son documentos, independientemente de si y en qué medida pueda decirse de ellos que fueron producidos por la actividad humana. Más bien se exige para el concepto de documento sobre todo que el objeto haga reconocible no meramente su propia existencia, sus propiedades naturales como las de un cuerpo determinado, su presencia en un lugar determinado en cierto momento; todo aquello lo hace reconocible o lo denota como una mera evidencia material. Para ser documento, debe permitir reconocer en él pensamientos humanos de algún contenido, sea que se trate de expresiones de voluntad, testimonios o informes; recién entonces funge el objeto no meramente como evidencia material sino que más allá de ello en virtud de su contenido espiritual en la comprensión de otros de ese contenido"; KienAPFEL (1967) p. 78, se trata aquí de una fórmula de compromiso con otra línea jurisprudencial del mismo Tribunal que define documento a partir del concepto jurídico-civil de declaración, como declaración fijada o corporeizada, de ahí que esta orientación reciba el nombre de teoría de la declaración (p. 72 y ss.); respecto de esta teoría, véase infra 2.3.).

32 Kienapfel (1967) pp. 114 y ss., 129 y ss. 
distinción propuesta por el RG y, sobre todo, la asimilación de los "signos probatorios" al concepto de documento, la que Binding rechaza enérgicamente: "El documento le habla a cualquiera que pueda leer su contenido, independientemente de dónde se encuentre. Es palabra humana plena de sentido, devenida autónoma, en su verdad garantizada por el otorgante. El signo probatorio no es vox mortua, sino que en sí un símbolo incomprensible, ya sea que no remite a ninguna persona fiable como su creador o como signo nominativo que prescinde de toda declaración (...)"33. Solo aquel que nunca ha reflexionado sobre la profunda oposición entre lenguaje y símbolo puede permitirse incluir los "signos probatorios" entre los documentos, afirma implacable ${ }^{34}$. "Todo lo legible y solo lo legible puede ser documento. Cuántos dominan este arte de la lectura, es indiferente" ${ }^{35}$. Es decir, Binding identifica a la lectura como criterio diferenciador del concepto de documento ${ }^{36}$. Pero, la lectura es la transformación de señales ópticas en las acústicas correspondientes y este proceso también puede ocurrir respecto de los "signos probatorios" ${ }^{37}$. Así, por ejemplo, se puede leer la placa patente de un vehículo e incluso su número de chasís inscrito en el motor. Si leer consiste en obtener un mensaje a partir de señales, entonces incluso las evidencias materiales serían también legibles, en la medida en que el receptor puede atribuirle un significado a los "signos naturales", aún sin la intervención de un emisor ${ }^{38}$.

¿En qué se diferencia entonces un documento de un objeto que sirve de evidencia? Recientemente, Puppe dice con razón que hoy sabemos un poco más sobre signos y su significado y sobre la forma en que funciona la comunicación, que en la época en que Binding escribía $^{39}$. Pero, precisamente en el mismo cambio de siglo, a varios centenares de kilómetros al suroeste de la ciudad donde el máximo jurista de la época publicaba su Tratado, Ferdinand de Saussure, el fundador de la lingüística, aclaraba el lugar que le corresponde a la escritura en el campo de los signos. Como todo fundador de una ciencia, su tarea radicaba en definir nítidamente su objeto de estudio. Según Saussure, el objeto de estudio de la lingüística es la lengua, entendida como un repositorio de las imágenes acústicas vehiculizadas mediante la palabra oral, los actos de habla ${ }^{40}$. La escritura tiene la virtud de poder fijar los signos de la lengua en imágenes convencionales, lo cual no es posible con los actos de habla, que no pueden ser fotografiados ${ }^{41}$. La lengua es un sistema de signos que expresa ideas, comparable con la escritura, el alfabeto de los sordo-mudos, los signos militares, es el más importante de estos sistemas. La ciencia que estudia la vida de los signos en general

\footnotetext{
33 Binding (1904) p. 180.

34 BINDING (1904) p. 180.

35 Binding (1904) p. 185.

36 En este sentido, Grisolía (1956) p. 95, en una nota de sentencia Corte de Apelaciones de Concepción, había advertido lúcidamente aquello que es común -contienen "signos de autenticidad"- y lo que diferencia al documento de billetes, estampillas, etc.: “(...) el documento, además de tener también formas de autenticidad (firma, sellos, etc.) posee un texto (...)” (destacado original), siguiendo a Soler (1967) p. 370 y s., que a su vez sigue a Binding.

37 Puppe (1972) p. 157.

38 Puppe (1972) pp. 25 y ss.

39 Puppe (2013) núm. marg. 12.

40 Saussure (1965) p. 32.

41 Saussure (1965) p. 32.
} 
en el seno de la sociedad es la semiología, por lo tanto, la lingüística es una parte de esta y su tarea es definir aquello que distingue a la lengua de los demás hechos semiológicos ${ }^{42}$. La razón de ser de la escritura es la de representar la lengua, lo que ocurre es que el prestigio de la escritura ha impedido ver que la lengua también tiene una tradición oral fijada de otra manera $^{43}$. La lengua está constituida de signos lingüísticos, entendiendo usualmente por signo la combinación de concepto e imagen acústica, por ejemplo, el concepto de árbol y la palabra "árbol”4. Según Saussure, se olvida que la palabra "árbol" es un signo en tanto que porta el concepto de árbol, que es parte del total. Propone entonces conservar la palabra signo y reemplazar concepto e imagen acústica por significado y significante, respectivamente ${ }^{45}$. El signo lingüístico es el total compuesto de las partes significante y significado. Lo que ocurre es que el nexo que une el significante al significado es arbitrario, en lo cual se distingue del símbolo, que tiene un rudimento de lazo natural con lo representado, por ejemplo, el símbolo de la justicia, la balanza, no podría ser reemplazado por un carro $^{46}$. En consecuencia, no existe una oposición profunda entre lenguaje y símbolo, como pensaba Binding. La lengua es un sistema de signos, el más importante entre los distintos signos estudiados por la semiología, según Saussure, y la escritura es otro sistema de signos que representa fielmente los signos lingüísticos.

En una perspectiva funcionalista, la discusión sobre la exigencia de escritura para el documento debe resolverse considerando la función que este cumple en el tráfico jurídico, arriba reseñada (supra 2.1.). Desde esta perspectiva, no cabe duda que la escritura, en tanto representante fiel de signos lingüísticos, es por excelencia el medio en el cual se realiza dicha función en el tráfico jurídico ${ }^{47}$. No obstante, esta afirmación obvia trae una consecuencia generalmente inadvertida, cual es que, entonces, una declaración acortada, una palabra, incluso abreviada, abreviaturas, siglas, hasta una letra, pueden ser documentos, porque todas se expresan en el medio de la escritura. Es mérito de Erich Samson haber llamado la atención al respecto, en su tesis doctoral publicada en 1968, y analizado, a partir de la teoría del signo, el mecanismo de funcionamiento comunicativo de estos textos fracciona$\operatorname{dos}^{48}$. En términos muy simplificados, este mecanismo consiste en la atribución de un significado a un signo conforme a una regla que se denomina código o clave ${ }^{49}$. Este proceso de atribución también ocurre en el lenguaje y la escritura, solo que de modo generalmente automático e inconsciente. El sistema de signos lingüísticos tiene un uso masificado y goza

\footnotetext{
42 SAussure (1965) p. 33.

43 SAUSSURe (1965) pp. 45 y ss.

44 SAUSSURe (1965) pp. 98 y ss.

45 SAUSSURe (1965) pp. 99.

46 SAussure (1965) pp. $100 \mathrm{~s}$.

47 En la doctrina nacional, GARRIDO (2008) p. 57 (destacado en original), siguiendo a la doctrina española, define documento como "manifestación de voluntad o consignación de hechos en forma escrita y más o menos permanente, realizada por una persona, que puede tener consecuencias jurídicas”, pronunciándose por la exigencia de escritura; en este sentido, también, Politoff et al. (2007) p. 559.

48 Samson (1968) pp. 65 y ss., 83 y ss.

49 SAmson (1968) p. 85 s., habla de clave (“Schlüssel”); Puppe (1972) p. 31 y ss., la llama código (“Code”); síntesis en un párrafo, Puppe (2013) núm. marg. 26.
} 
de estabilidad ${ }^{50}$. En cambio, en el mismo sistema de signos, el mecanismo se vuelve consciente, cuando se trata de una lengua muerta (v.gr.: el arameo), pues la clave es conocida y usada en un círculo científico, al cual es preciso recurrir para llevar a cabo el proceso de atribución ${ }^{51}$. En una posición comparable se encuentran los lenguajes codificados, por ejemplo, el alfabeto Morse o las claves usadas en instituciones armadas (v.gr.: "zafarrancho"). El problema que se plantea en estos sistemas de signos es que son conocidos y usados en círculos reducidos, por lo que se ven expuestos a mayores posibilidades de modificaciones, pueden volverse inestables. Para que presten un rendimiento comparable con la lengua y la escritura, es preciso que el signo y la clave sean perdurables, además de ser reconocible el nexo entre ambos ${ }^{52}$. Por último, las abreviaciones se caracterizan por contener una parte reconocible en el medio del lenguaje y de la escritura -parte decodificada- y otra en lenguaje codificado. Para que presten un rendimiento comparable a la escritura, la parte codificada debe ser suficientemente estable y además reconocible en un círculo de uso ${ }^{53}$. El análisis del mecanismo comunicativo en los ejemplos del lenguaje codificado y de las abreviaciones muestra que, dadas estas condiciones, es posible prestar un rendimiento comparable al característico de la lengua y la escritura también mediante la fijación de signos no lingüísticos.

Sin embargo, Ingeborg Puppe se pregunta ${ }^{54}$, ¿porta la palabra humana su sentido como una vasija su contenido? ¿Es equiparable el significado atribuido a un signo a la propiedad corporal de un objeto, por ejemplo, el color rojo de un auto? Si esta pregunta se contestara afirmativamente, entonces la atribución de un significado a un signo sería comparable a la actividad de pintar de rojo una cosa. Pero, la comunicación no funciona así. El proceso de atribución de significado a un signo, lingüístico o no, opera siempre en una relación entre emisor y receptor de la información, en que ambos ocupan el mismo código $^{55}$. La atribución de significado por parte del receptor también puede suceder respecto de un objeto, por ejemplo, cuando Otelo atribuye la infidelidad al pañuelo dejado por Jago. Pero, y en esto radica la diferencia, en la comunicación mediada por un documento, el emisor de la información elige o determina el código fijado y usado luego por el receptor $^{56}$. Como explica Puppe, el emisor puede elegir libremente los signos que forman parte del acervo común a ambos, tiene el dominio de la información ${ }^{57}$. Esta elección no se produce respecto de "signos naturales" o señales ("Anzeichen"). Si bien estas pueden tener un significado, por ejemplo, una huella digital puede significar que un sujeto ha tocado ese objeto, este no surge de una atribución al signo. El sujeto puede causarla, pero no es su expresión ${ }^{58}$. En consecuencia, por sí mismos los "signos naturales" no constituyen docu-

\footnotetext{
50 SAussure (1965) pp. 104 y ss., sobre la inmutabilidad (y mutabilidad gradual) de la lengua.

51 SAMSON (1968) p. 123.

52 SAMSON (1968) pp. 125 y ss.

53 SAMSON (1968) pp. 130 y ss.

54 Puppe (2013) núm. marg. 12.

55 Puppe (2013) núm. marg. 12, 26.

56 Puppe (1972) p. 30, 34

57 Puppe (2013) núm. marg. 29.

58 Puppe (2013) núm. marg. 27.
} 
mento, sino que objetos de evidencia material. Este principio puede sufrir dos excepciones. Primero, en el caso en que el objeto se conecta de tal manera con una declaración, que puede considerarse parte de un documento -el denominado "documento compuesto". Segundo, en los casos límite en que la mera señal se convierte en una declaración por obra de una persona- los así llamados "signos probatorios".

Un "signo natural" puede excepcionalmente constituir un documento junto a una parte escrita cuando concurren ciertos presupuestos. Un ejemplo polémico es el informe de alcoholemia, en la medida en que puede distinguirse el texto del informe de la muestra de sangre que es en principio mera evidencia material ${ }^{19}$. En este tipo de casos, en la doctrina alemana se han delineado exigentes criterios para estar en presencia de lo que se llama un "documento compuesto" ("zusammengesetzte Urkunde") ${ }^{60}$. Primero, deben existir dos partes, una escrita y otra que consiste en un objeto de evidencia material, suficientemente unidas externamente. Ambas partes deben encontrarse destinadas a cumplir un fin probatorio y perdurar unidas lo suficiente hasta alcanzar el fin. La parte escrita debe contener una declaración, que requiere ser complementada con la parte no escrita. Esta necesidad de complemento debe surgir del texto de la declaración, aunque sea implícitamente. La parte no escrita, a su vez, debe ser apta para rendir este complemento como mera evidencia material. En el ejemplo mencionado del informe de alcoholemia, puede resultar dudosa la configuración de un "documento compuesto", solamente en la medida en que, respecto del primer criterio exigido, el nexo externo que une ambas partes no sea lo suficientemente firme y duradero ${ }^{61}$.

En el caso de los así llamados "signos probatorios" el problema de delimitación es particularmente difícil. Por ejemplo, el timbre impreso en un animal, el número de chasís

\footnotetext{
59 Sanhueza (1991) pp. 35 y ss., en un caso en que paramédicos de un hospital cambiaban frascos de sangre de imputados por muestras de la propia sangre de ellos, con la finalidad de obtener informes de alcoholemia sin signos de presencia de alcohol, previo pago de una suma de dinero por parte de los interesados (p. 36); dado que el Director del Hospital firmaba los informes de alcoholemia sin saber que las muestras de sangre no correspondían a los imputados, según la autora del comentario concurre una hipótesis de autoría mediata por error de tipo, provocado por los paramédicos que no actuaron como funcionarios públicos, en definitiva impune por tratarse "la falsedad ideológica" de un "delito especial propio" (p. 39 s.); sin embargo, el art. 193 CP es un delito especial, pero no el art. 194, cuyo tipo no exige ninguna circunstancia especial respecto del sujeto activo ("el particular que..."); la autora del comentario incurre en un error metodológico al tratar de resolver el caso en sede de participación, sin previamente reflexionar sobre los elementos del tipo del art. 194 del CP, partiendo por la pregunta determinante: ¡es un informe de alcoholemia un documento en el sentido de dicho tipo penal? 60 LAMPE (1957) pp. 62 y ss.

61 LAMPE (1957) pp. 64 y ss., respecto del caso decidido en BGHSt. 5, 75; más categórico Samson (1968) p. 137 y ss., "el nexo entre escrito y cosa es, como todo elemento descriptor de la cosa, solo objeto de la declaración y no parte de ella”; relativiza Puppe (1972) p. 196 (nota 1), en tanto el signo refiere a la cosa como objeto de la declaración, el nexo entre ambos forma parte de esta; "toda situación objetual funge como signo, en tanto es producida para entregar al receptor de la expresión una información que sirve a su comprensión y de este modo es parte de esa expresión” (p. 201); en este sentido también JAKOBS (2000) p. 86, en la medida en que el objeto en cuestión se encuentre unido fijamente con el resto de la declaración, no porque así se vuelva evidente a qué objeto se refiere, sino porque el vínculo es un gesto declarativo comprensible para cualquiera, con el cual la parte de la declaración expresada en palabras o símbolos se refiere al objeto "signado": "cierto, el objeto mismo sigue siendo mera evidencia material, pero el vínculo es un gesto declarativo” (destacado original).
} 
inscrito en el motor de un vehículo ${ }^{62}$. Es un problema de interpretación del signo distinguir en el caso si se trata de la fijación de la expresión de una persona o mero resultado de la acción humana ${ }^{63}$. Si el signo se fija en el objeto con el solo efecto de poder reconocerlo en el futuro y distinguirlo de otros del mismo tipo, entonces parece forzado sostener que el objeto signado es expresión de pensamiento o declaración de la persona, pues no se puede declarar sobre un acontecimiento futuro. Si una persona sabe que el motor de su auto tiene inscrito un número determinado de chasís y posteriormente vuelve a ver el número, por ejemplo, para reconocer si el auto previamente robado y recuperado es efectivamente su auto, entonces puede interpretar el número en el sentido de saber que ese es el auto sobre el cual antes sabía que portaba ese número ${ }^{64}$. Como puede verse en esta explicación, el signo consistente en un número aparece nuevamente en el lado del significado, el número XY significa que el vehículo circula bajo el número XY, ergo, el signo se significa a sí mismo ${ }^{65}$. En cambio, el caso de la placa patente de un vehículo puede ser distinto, en la medida en que esta cumpla un rol que trascienda la mera individualización del auto (véase: art. $2 \mathrm{~N}$. 36 Ley de Tránsito) y pueda interpretarse como una declaración de la autoridad de permiso para circular en la vía pública ${ }^{66}$. En conclusión, este análisis releva como criterio diferenciador entre "signos probatorios" y meros signos o señales la existencia de una declaración, reconducible a una persona. De ahí que sea más preciso hablar de signos declarativos y distinguir entre estos, que pertenecen al concepto de documento, y los meros signos o señales, que solo constituyen objeto de evidencia material ${ }^{67}$.

\subsection{TeOría de la deClaración: El documento es lo CONTRARio de Un Objeto}

La identificación de la existencia de una declaración como criterio delimitador del concepto de documento entronca con una línea jurisprudencial sostenida ya por el Tribunal Supremo del Reich en Alemania (Reichsgericht), a fines del siglo XIX ${ }^{68}$. Esta línea jurisprudencial define documento en base a una categoría tomada del Derecho civil, como es aquella de la declaración, en oposición a otra línea, ya mencionada arriba (supra 2.2.), que recurre a la palabra objeto para tal definición ${ }^{69}$. Tal línea jurisprudencial opone a esta

\footnotetext{
${ }^{62}$ Otro ejemplo, donde el punto puede discutirse, Contra Minder (1943): "discos" distintivos de automóviles particulares.

63 Puppe (2013) núm. marg. 27.

64 Puppe (2013) núm. marg. 32.

65 Puppe (1972) p. 135.

${ }^{66}$ Según las reglas del Derecho de Tránsito, art. 38 y ss. Ley de Tránsito (N. 18.290); en todo caso, en nuestro contexto esta discusión se vuelve menos relevante para efectos prácticos por la existencia de un tipo penal especial que castiga expresamente la falsedad cometida en las inscripciones a que se refieren los artículos mencionados de la Ley de Tránsito (art. 190 letra c).

${ }^{67}$ Puppe (2013) núm. marg. 35.

68 RGSt. 13, 71 (fallo de 26 de octubre de 1885): "en el caso de un documento privado que consiste en un escrito, se trata siempre de una declaración de un particular puesta en un escrito, cuyo efecto y contenido se fija en el escrito y precisamente por eso es probatorio mediante el mismo" (p. 73).

69 De ahí que Kienapfel (1967) pp. 72 y ss., denomine dicha línea jurisprudencial teoría de la declaración, la que, sin embargo, no fue consecuente y persistentemente sostenida por el RG en el tiempo, llegando más bien a fórmulas de compromiso con su opositora teoría del objeto.
} 
una teoría de la declaración en la dogmática del documento. Según esta concepción, documento es una declaración de una persona fijada por escrito. El contenido de esta declaración puede ser de dos tipos, que dan lugar a su vez a dos clases de documentos ${ }^{70}$. Si expresa una voluntad de disposición, ejemplo, un acto o contrato, se trata de un documento dispositivo. Si expresa la observación de una circunstancia fáctica, ejemplo, que una persona se encuentra viva, se trata de un documento testimonial. Pero, si documento se define a su vez como una declaración, ¿es esta distinta del contenido que da cuenta? En este sentido, se puede decir que un documento dispositivo da cuenta de la realización de una declaración de voluntad o que un documento testimonial prueba la ejecución de la observación de un hecho ${ }^{71}$. Sin embargo, si esto es así, entonces tanto una declaración de voluntad como una de conocimiento también pueden probarse mediante una declaración oral. Pero, ¿se encuentra el documento con respecto a una declaración de voluntad o testimonial en la misma relación que una declaración oral? O, preguntado de otra manera, ‘acaso no tiene el documento un significado propio?

Como fue analizado previamente (supra 2.1.), la ventaja comparativa radica en que al ser proyectada la declaración de voluntad o de conocimiento en el documento puede conservarse y ser reproducida nuevamente en todo momento ante otros, no se desvanece junto con la palabra hablada ${ }^{72}$. El rendimiento propio del documento deriva de esta fijación de la declaración de voluntad o de conocimiento. Esta perpetuación de la declaración

\footnotetext{
70 Explica JAKOBS (2000) p. 61 s., se documenta una declaración, falta esta, no hay nada que documentar; "El Derecho decide qué es una declaración"; no obstante, el Derecho civil denomina "declaraciones nulas" expresiones que no constituyen declaración en sentido jurídico-penal, así en los casos de nulidad por contravención de una prohibición legal ( $\$ 134$ Bürgerliches Gesetzbuch: BGB) o de las buenas costumbres $(\$ 138$ BGB), son no declaraciones, porque no pretenden ningún efecto jurídico, aun cuando concurra una voluntad fácticamente vinculante, ejemplo, un acuerdo de esclavitud.

71 Así RGSt. 17, 103, p. 107 y s.: "Más bien el fin, al cual sirve la fijación documental de pensamientos, debe estar dirigido a comprobar mediante la expresión de pensamiento allí contenida la presencia o no presencia de un hecho, que no consiste solamente en la expresión misma de pensamiento, y esto debe suceder con el fin de hacer creíble el hecho para otras personas. No es necesario que la circunstancia fáctica se encuentre completamente fuera de la expresión, que se refiere a aquella, pues en la expresión de actos de voluntad dispositivos en un escrito coincide la realización del acto de voluntad en parte con su expresión; pero se debe probar mediante el escrito no meramente la expresión, sino que también la existencia del acto de voluntad. En todos los documentos no dispositivos el hecho a probar mediante los mismos se encuentra fuera de la expresión contenida en el documento; entre estos se cuentan los testimonios fijados en escritos o corporalmente de otro modo sobre observaciones de un acontecimiento, que alguien ha realizado; este quiere primero que el escrito pruebe que él ha expresado observaciones y cuales, quiere no obstante también que el hecho consistente en que él ha expresado sus observaciones sirva para la prueba de que el acontecimiento ha ocurrido. Con su determinación de voluntad dirigida a este último fin en los testimonios escritos, así como en los documentos dispositivos con la intención dirigida a la prueba de la existencia del acto de voluntad, se completa el concepto de documento, bajo el presupuesto de que también concurre el atributo de la capacidad probatoria. Pueden concurrir otras características además de las mencionadas, sirven sin embargo solamente para la diferenciación de las diversas clases posibles de documentos. Entre estas pueden mencionarse los elementos según los cuales se distingue un documento jurídicamente relevante de otro jurídicamente irrelevante, uno público de otro privado, uno probatoriamente relevante de un documento privado no relevante probatoriamente. Estos elementos son importantes especialmente para la pregunta de si en relación a un documento determinado se puede cometer un delito determinado; pero, para el concepto de documento mismo, carecen de relevancia” (destacado agregado).

72 Kohlrausch (1929) p. 336, primera columna.
} 
es a su vez producto de una decisión. Kohlrausch la compara con la promulgación de una ley. Del mismo modo en que el legislador junto con sancionar el contenido de la ley la promulga (“ita ius esto?”), también en la documentación junto con expresar una declaración se manifiesta la voluntad de atenerse a la palabra: "esta es mi palabra"73. En este sentido, el ordenamiento jurídico le concede a los sujetos que participan en el tráfico la libertad para configurar relaciones jurídicas, creando derechos y obligaciones mediante actos jurídicos. Pero además, el ordenamiento jurídico también les concede a las personas la libertad de expresar oralmente o fijar por escrito sus declaraciones de voluntad o de conocimiento. Si la persona opta por fijar por escrito su declaración, debe responder por ello. Como lo esclarece Puppe: "Quien otorga un documento, decide sobre su contenido. Por eso, es su declaración"74. La persona goza de la libertad para fijar el contenido del documento, consecuentemente, debe responder por este ${ }^{75}$. El significado propio de la documentación consiste en que mediante el documento el otro puede saber quién debe responder jurídicamente por la declaración contenida en él. Este significado concurre tanto en el documento dispositivo como en el testimonial. Para que los actos jurídicos puedan producir sus efectos, es presupuesto básico que la declaración pueda imputarse a un sujeto jurídico ${ }^{76}$. La documentación, es decir, el acto de otorgar un documento, es también un acto jurídico. Si no fuera así, el documento estaría fuera del ordenamiento jurídico, sería algo así como su "cáscara". No, la documentación es parte del ordenamiento jurídico. En tanto acto declarativo, clase de declaración, se distingue de los demás actos jurídicos en la particularidad de que mediante la documentación la persona pretende atribuir un efecto jurídico a su propia palabra: "el ordenamiento jurídico puede concederle este efecto solo bajo la condición de que el sujeto por su parte responda por su palabra"77. En síntesis: "el documento es una declaración fijada, producto inmediato de un acto declarativo y expresión duradera de una voluntad o de una afirmación jurídicamente eficaz del sujeto"78. A esta expresión, el Derecho le asigna sus consecuencias, porque no puede atribuirlas a una voluntad no manifestada o directamente al conocimiento de una persona ${ }^{79}$. La consecuencia jurídica atribuida

\footnotetext{
73 Kohlrausch (1929) p. 336: „Das soll mein Wort sein!“.

74 Puppe (1972) p. 14 (destacado agregado).

75 Se trata entonces de la relación sinalagmática entre libertad de acción y responsabilidad por las consecuencias, JAKOBS (2000) pp. 39 y ss.

76 Puppe (1972) pp. 173 y ss.

77 Puppe (1972) pp. 174.

78 Puppe (1972) pp. 175; similar concepto en JАKOBs (2000) p. 51: "documento es toda declaración corporeizada que pretende provocar efectos jurídicos, sea que estos radiquen en una configuración (documentos dispositivos y aquellos testimoniales que los sustituyen) o en la fe pública en la corrección de una afirmación jurídica (documentos testimoniales que surgen en plena fe)"; la documentación de la declaración prueba quién pretende provocar un efecto jurídico, esta es la expectativa garantizada por la prohibición de la falsedad documental; por eso JAKOBS (2000) p. 58 y s., sostiene que el tráfico interno "documental", en tanto no configura relaciones jurídicas, no es tráfico jurídico, que solo es realizable entre personas: "dentro de una persona no hay nada jurídicamente vinculante que configurar, por lo tanto, tampoco nada que probar e igualmente nada que documentar" (destacado original).

79 Puppe (1972) p. 175.
} 
inmediatamente al otorgamiento de un documento radica en el deber de responder por su contenido.

En este sentido, Binding sostiene que el otorgante del documento responde como garante por la verdad de su declaración. El valor probatorio del documento deriva no de su forma escrita - "la palabra escrita, salvo excepciones legales, no prueba más que la oral”-, sino de la circunstancia que una persona determinada responde por la verdad de la declaración documentada ${ }^{80}$. Por eso, considera que en todo documento deben concurrir dos elementos esenciales al mismo, una declaración y un garante de verdad, el otorgante ${ }^{81}$. Binding se refiere a la "seriedad" ("Ernstlichkeit") como característica esencial del documento: "su otorgante debe mediante este pretender realmente declarar una voluntad jurídicamente relevante o responder por una circunstancia fáctica verdadera o no como garante de verdad" 82 . No obstante, precisa que la "seriedad" exigida se refiere solamente a la voluntad de declarar o manifestar lo que en el documento aparece escrito ${ }^{83}$. De este modo, Binding subjetiviza un elemento que pudo concebirse en términos normativos. Esta subjetivización es consecuente con su punto de partida, que es una teoría probatoria del documento ${ }^{84}$. Dice: "Lo que es documento y lo que no es, sobre ello decide naturalmente no el Derecho penal, sino el Derecho probatorio" ${ }^{\prime 5}$. Y agrega: "La historia entera de la prueba jurídica es en gran parte ampliación de las posibilidades de prueba mediante ampliación y multiplicación de los medios de prueba" ${ }^{16}$. Por eso, Binding admite la discutida figura del así llamado "documento casual", junto al intencional, en el concepto de documento ${ }^{87}$. Por ejemplo, la carta de amor, con relevaciones comprometedoras del marido infiel, destinada a su amante, encontrada y presentada por su esposa como medio de prueba en el proceso de divorcio. Según Binding, la intención de usar el escrito como medio de prueba no influye en su contenido. El descubridor del documento casual normalmente debe establecer primeramente la conexión de la circunstancia fáctica manifestada en él con una relación jurídica determinada. Pero, recién su voluntad de probar con este convierte al escrito en documento y desde ese instante goza también de protección jurídica ${ }^{88}$.

Sin embargo, como explica Puppe, el contenido de la voluntad "esto vale como mi palabra para el tráfico" es distinto que la voluntad "con esta palabra (de otro) quiero probar que..." 89 . La primera solo puede expresarla el otorgante del documento, mientras que la segunda puede ser expresada por cualquiera que participa en el tráfico jurídico. Cualquiera

\footnotetext{
80 BINDING (1904) p. 195.

81 Binding (1904) p. 196.

82 BINDING (1904) p. 207.

83 Binding (1904) p. 207 "así, documento es un escrito mediante el cual el otorgante responde por la verdad de una circunstancia fáctica jurídicamente relevante allí contenida, esto es, manifestada” (p. 208).

84 Critica esta concepción probatoria García Cantizano (1997) p. 38 y ss.

85 Binding (1904) p. 188, en contra de la teoría del objeto sostenida en la misma época por MerKEL (1889).

86 Binding (1904) p. 189.

87 BiNding (1904) pp. 189 y ss.; JAKOBS (2000) p. 56 nota 91, advierte aquí una contradicción de Binding al admitir, por una parte, la figura del "documento casual" y al definir, por otra, documento como un escrito en que el otorgante responde por su verdad.

88 Binding (1904) p. 191.

89 Puppe (1972) p. 126.
} 
puede convertir un mero escrito en un documento mediante su determinación probatoria, esto es, imprimiendo a aquel el fin subjetivo de probar una circunstancia fáctica jurídicamente relevante ${ }^{90}$. Pero, respecto de la ocurrencia de este hecho, la identidad del redactor original del escrito entrega solamente un indicio, tal como por ejemplo, las huellas de neumático en una calle pueden indicar la ocurrencia de un accidente ${ }^{11}$. Para volver al ejemplo de la carta del amante, saber quién la redactó entrega solo un indicio de la configuración fáctica de una causal de divorcio. El redactor original del escrito no se convierte en garante de su contenido por la circunstancia de que posteriormente alguien pretenda probar algo con su expresión ${ }^{92}$. El reconocimiento del "documento casual" implicaría que cualquier escrito que indirectamente sirve para probar la ocurrencia de un hecho, esto es, mediado por la determinación probatoria de un tercero, sería documento. Este reconocimiento del "documento casual" como documento, sin embargo, desconoce el significado propio de éste $^{93}$. El significado propio del documento no radica en ser especialmente apto para la prueba. En esta aptitud probatoria, el documento no presta una ventaja especial que lo distinga de una declaración oral. El significado propio del documento consiste en que inmediatamente, por sí mismo produce un efecto jurídico, ya sea que porte en sí la declaración de voluntad, como en el documento dispositivo, o porque contiene la observación de una circunstancia fáctica jurídicamente relevante, como en el documento testimonial ${ }^{94}$. Ese efecto jurídico inmediatamente asignado al documento consiste en que el otorgante del mismo debe responder por su contenido. Este efecto jurídico no depende de su voluntad. De su voluntad depende la decisión de fijar una declaración determinada y no dejarla entregada a la perecedera palabra oral. Una vez ejercida esta libertad, el ordenamiento jurídico le atribuye como efecto el deber de responder por el contenido expresado en el documento.

Esta voluntad de declaración falta también en el así llamado "documento conjunto" (“Gesamturkunde”). Este surge del cumplimiento de un deber jurídico, basado en la ley, la costumbre o el acuerdo de las partes, que obliga a registrar correcta y cabalmente un conjunto de actividades en un ámbito de la vida mediante anotaciones individuales que en su completitud adquiriría carácter documental ${ }^{95}$. Un ejemplo de deber jurídico de documentación es el establecido en los art. 25 y ss. del Código de comercio, que obligan al comerciante a llevar registro contable de todas las operaciones mercantiles realizadas ${ }^{96}$. Por ejemplo, un comerciante lleva registro de los consumos realizados por un académico en una cafetería, para luego cobrarle periódicamente una suma total, no obstante, un día el empleado de la cafetería anota 0 pesos donde debía decir 500 pesos por el consumo de un café. La pregunta es, en el ejemplo, si la hoja con la totalidad de anotaciones registra-

\footnotetext{
90 Kienapfel (1967) pp. 193 y ss., se trata de un principio subjetivo, que se opone a la exigencia objetiva de aptitud probatoria; dicho principio subjetivo se vuelve criterio rector de la jurisprudencia del RG.

91 Ejemplo de Erb (2011) p. 1110.

92 Puppe (2013) núm. marg. 9.

93 También en contra, JAKOBS (2000) p. 56 y ss.

94 ERB (2011) p. 1111.

95 LAMPe (1957) p. 17 y ss.

96 Otro ejemplo, los libros de registro notarial (art. 429 ss. COT), contra Tejías (1955); en la doctrina nacional, se pronuncia en contra de esta figura del documento conjunto, GUZMÁn Dalbora (2007) p. 452 y ss.
} 
das, incluida la que señala 0 pesos, es un documento "conjunto". Sin embargo, como se ha visto previamente, un documento presupone un otorgante y, si uno se fija, acá no hay una persona que otorgue la hoja con el total de anotaciones como un documento. Cierto, hay una persona que ingresa las anotaciones individuales, en el ejemplo, el empleado de la cafetería, pero estas no interesan por sí mismas, sino en su conjunto, y, por lo tanto, tampoco resulta determinante quién es autor de las mismas, este es reemplazable. El creador del "documento conjunto" es la propia ley, que contiene una voluntad objetiva que se expresa en él. En este sentido, Lampe dice que aquí se asiste a una objetivización del sujeto y su voluntad que conduce a una "despersonalización”, porque el deber jurídico mismo, que crea el "documento conjunto", no es "capaz de acción, es mudo y se dirige con su 'tú debes' a la facultad decisoria del individuo" 97 . Puede motivar la voluntad de este, incluso para que otorgue documentos individuales, pero por sí mismo el deber jurídico no es capaz de otorgar un documento. En el mismo sentido, Puppe advierte que en el así llamado "documento conjunto" solo queda la "fachada" del documento, pues no existe otorgante ni voluntad de declaración ${ }^{98}$.

\subsection{CONClusión}

De este modo, es posible arribar al siguiente concepto de documento: es una declaración de una persona fijada en signos que expresan en el tráfico jurídico un acto de voluntad o la observación de una circunstancia fáctica jurídicamente relevante. Este concepto se inscribe en la tradición de la teoría de la declaración (supra 2.3.). Se trata de la declaración de una persona, es decir, aquella debe ser atribuible a un sujeto jurídico. Precisamente, aquello que caracteriza y distingue la documentación de una declaración entregada a la palabra oral (supra 2.1.) radica en que ese nexo de atribución entre persona y declaración se fija en el documento. Por ende, documento es fijación de una declaración. Esta fijación normalmente se realiza en el medio de la escritura, sin embargo, también puede efectuarse, concurriendo ciertos presupuestos, en otros signos no lingüísticos, por ej. en lenguaje codificado (supra 2.2.). Por eso, se define documento como la fijación en signos de la declaración de una persona. Esta fijación en signos se inserta en el tráfico jurídico, es decir, sirve a la producción de efectos jurídicos, no meramente probatorios (supra 2.1.). Estos efectos jurídicos derivan directa o indirectamente del contenido de la declaración fijada en signos. Si estos expresan un acto de voluntad (manifestación o declaración de voluntad), entonces los efectos jurídicos nacen directamente de esta y se está en presencia de un documento dispositivo, por ej. una escritura de compraventa o un documento administrativo. Si los signos expresan solamente la observación de un hecho jurídicamente relevante, entonces los efectos jurídicos se producen en la medida en que realmente ha ocurrido el hecho y se está en presencia de un documento testimonial, por ej. el recibo de un pago o un certificado de defunción. Lo común a ambas clases de documento radica en lo siguiente: al optar el sujeto jurídico por fijar en signos su declaración de voluntad o testimonial, queda vinculado normativamente a esta, debe responder por su contenido (supra 2.3.).

97 LAMPe (1957) p. 56 y ss.

98 Puppe (1972) p. 141 y ss. 


\section{CONSECUENCIAS DE LEGE LATA DEL CONCEPTO DE DOCUMENTO}

\subsection{UnA APROXIMACiÓn METOdOlÓgICAMENTE Distinta: LA PREgUnTA POR EL DOCUMENTO}

La aproximación precedente al concepto de documento implica un giro metodológico en el análisis de los tipos de los arts. 193, 194 y 197 CP. Vuelca la mirada a un aspecto tradicionalmente más bien despreciado en la doctrina y jurisprudencia. Conduce a desviar la atención desde una simple característica o atributo como es el carácter público o privado hacia una cuestión fundamental como es la pregunta por la existencia de un documento. La consecuencia metodológica es tan simple como la formulación de una pregunta previa en el análisis de la configuración de los tipos de los arts. 193, 194 y 197 CP. En concreto, antes de ir a la pregunta por el carácter público o privado del documento, debe lógicamente analizarse si se trata de un documento. Para siquiera entrar al ámbito de aplicación de la norma subyacente a los tipos de los arts. 193, 194 y 197 CP, debe contestarse la pregunta por el documento. Dicho de otra manera, antes de preguntarse si se trata de un documento público o privado, debe tratarse de un documento. Pues, lo público o privado del documento, es solo un atributo del mismo. Pero, esta pregunta previa no se formula para efectos puramente teóricos, sino que para la eventual aplicación de la ley penal en una hipótesis fáctica de falsedad documental, es decir, en que se ha creado lo contrario de un documento en el sentido arriba analizado (supra 2.4.). Por lo tanto, metodológicamente el ejercicio que debe hacerse antes de consultar por el carácter público o privado que habría revestido el documento, es el siguiente: si ese escrito o esa fijación de signos fuera verdadero, ¿sería un documento? Si la respuesta a esta pregunta es negativa, entonces decae el primer requisito para siquiera entrar en el ámbito del sistema de los delitos tipificados en los arts. 193 a 198 del Código penal y el análisis debe concluirse inmediatamente en ese momento. Conforme al análisis precedente del concepto de documento, la respuesta es negativa siempre que se trate en el caso concreto de "signos naturales" o meras señales, de un "documento" casual o de un "documento" conjunto, aun cuando todos ellos sean aptos para la prueba de un hecho relevante. En cambio, si la respuesta a esa pregunta es positiva, esto es, efectivamente se trataría de un documento si fuera verdadero, entonces luego es preciso consultar, si este sería público o meramente privado. Conforme al análisis precedente del concepto de documento, la respuesta es positiva, en primer lugar, si se trata de la fijación por escrito o en signos que expresan un acto de voluntad, esto es, el ejercicio de la libertad de disposición de una persona (documento dispositivo). La respuesta a esa pregunta es positiva, en segundo lugar, si se trata de la fijación por escrito o en signos que expresan la observación de un hecho jurídicamente relevante (documento testimonial).

Luego, es preciso analizar, si este documento dispositivo o testimonial, de ser verdadero, sería público o sería meramente privado, porque la respuesta a esta pregunta conduce al ámbito de aplicación de la norma del art. 193 y 194 CP o al ámbito normativo del art. 197 CP, respectivamente. Esto es, si el documento dispositivo o testimonial sería público de ser verdadero, se entra en el ámbito normativo del art. 193 y 194 CP. Si en cambio, el documento dispositivo o testimonial no sería público, sino que meramente privado, se ingresa al 
ámbito normativo fijado por el tipo del art. 197 CP. En este contexto, la exigencia expresa del "perjuicio de tercero" de este tipo penal evoca el elemento del "praejudicium alterius" formulado por la doctrina italiana medieval tardía en el desarrollo del concepto de "crimen falsi", donde aquel no se comprendía como perjuicio en el sentido moderno de los delitos patrimoniales, sino más bien solamente como una aptitud ("apta erat nocere") de la falsedad para dañar los derechos de un tercero, vale decir, en la falsedad documental del eventual receptor del documento falso ${ }^{99}$. Esta posibilidad de lesión a los derechos de un tercero viene dada siempre que este, el documento falso, de ser verdadero, sería un documento dispositivo o testimonial, pues este contiene ya en sí la referencia a los derechos del receptor del documento, que en caso de falsedad podría inducir a una representación falsa sobre la existencia de un documento dispositivo y, por lo tanto, de la creación de los derechos y obligaciones propios del acto de voluntad que contiene, o sobre la existencia de un documento testimonial y, por ende, de la generación de los efectos jurídicos propios del hecho constatado. El requisito expreso de "perjuicio a tercero" contenido en el tipo del art. 197 inciso $1^{\circ} \mathrm{CP}$ radica en una "cláusula de relevancia" típica, cuya función es meramente heurística, esto es, recuerda al aplicador de la ley penal la necesidad de dar el paso metodológico previo de preguntarse si el documento, de ser verdadero, sería dispositivo o testimonial.

Es un documento público, por ejemplo, una escritura pública en el sentido del art. 1699 inc. $2^{\circ} \mathrm{CC}$ y del art. 403 COT. Pero también lo es todo documento que la regla de una ley especial así lo establece, por ejemplo, el certificado de conformidad de una exportación según el art. 28 inc. $1^{\circ}$ de la Ley 19.545 de 1998 o el certificado de un hecho relevante según el art. 10 inciso $3^{\circ}$ de la Ley de Pesca N. 19.713 de 2001. En cambio, es un documento privado todo aquel que no está dotado de la presunción de autenticidad propia de un documento público.

\subsection{EXCurso sobre el documento electrónico (Ley N. 19.799 de 2002)}

Históricamente, el documento se ha vertido en soporte de papel. Este medio permite la fijación de signos que no es posible en la palabra oral. Esta no puede verse, ni tampoco es perdurable, sino que siempre perecedera. En cambio, al fijarse una declaración en el sopor-

99 Rojas (2012) p. 554 y ss., 560 y ss., 567, 579 y ss.; en este sentido, recientemente VARGAS (2013) pp. 96 y ss. critica la configuración patrimonial del perjuicio en el art. 197 CP, esto es, la comprensión del perjuicio en el sentido de lesión patrimonial; luego, la misma autora discurre en torno a la tesis de la conservación de las condiciones de circulación en el tráfico jurídico como estado que interesa proteger frente a conductas que importen un peligro abstracto o un peligro concreto asociado al uso (pp. 125 y ss., en especial, pp. 129 y ss.); sin embargo, por la forma en que se configura este requisito en el tipo del art. 197 (p. 135), concluye que perjuicio exige "la lesión de un bien individual ajeno" (p. 137); crítico también, Londoño (2010) p. 65, respecto de la configuración patrimonial del perjuicio, si presupone una conexión inmediata con la conducta típica, entonces solo puede ser resultado de la conducta típica de "uso malicioso" (art. 198: "En efecto, solo en dicho contexto puede apreciarse un perjuicio vinculado causal y funcionalmente al uso malicioso (engaño)"); si perjuicio significa lesión al patrimonio, entonces ninguna conducta típica de falsedad puede encontrarse en una conexión de inmediatez con el perjuicio así comprendido, por la simple razón de que este presupone el uso del documento falso, dicho con otras palabras, siempre media entre la conducta típica de falsedad y el perjuicio en su configuración patrimonial la conducta típica de uso (art. $198 \mathrm{CP}$ ); por eso, Londoño (2010) p. 67, concluye que la falsedad, para ser delito, "debe estar connotada de una base mínima de idoneidad para causar un perjuicio típico”, aptitud que se traduce necesariamente en el uso del documento falso. 
te de papel, mediante impresión o manuscritamente, esta se vuelve visible y legible, además de perdurable por todo el lapso previo al deterioro o la destrucción. De ahí que las reglas del Código civil (art. 1700 y ss.) relativas, en general, a los documentos públicos y privados y las del Código orgánico de tribunales (art. 403 y ss.) referidas, en particular, a las escrituras públicas, partan de la premisa obvia que el documento se vierte en soporte de papel. Sin embargo, ni unas ni otras reglas exigen expresamente que se trate solo de este tipo de soporte material. Estas normas prepenales establecen una serie de exigencias relativas más bien al contenido del documento (cfr. art. 1700 CC, art. 405 COT) y al procedimiento de su otorgamiento que a las formas que puede revestir. En consecuencia, una declaración puede ser fijada en cualquier soporte, en la medida en que este posibilite la visibilidad de los signos y sea perdurable ${ }^{100}$. En este sentido, ya Binding advertía que no había nada más informal que un documento privado e incluso que el documento público tendía crecientemente al abandono de la forma ("Formverwilderung"), porque no la forma, sino el contenido del documento es lo que se usa para la prueba falsa ${ }^{101}$.

Un documento también puede verterse en un soporte electrónico, en la medida en que este rinda un grado de fijeza equivalente al del papel. Esta equivalencia entre el soporte electrónico y el soporte de papel ha sido establecida legislativamente como un principio en el art. 1 inc. $2^{\circ}$ de la Ley 19.799, "sobre documentos electrónicos, firma electrónica y servicios de certificación de dicha firma”. Lo determinante es que se reúnan los elementos del documento, previamente analizados, esto es, una declaración dispositiva o testimonial, expresada en signos y atribuible a una persona. La posibilidad de fijar tales declaraciones en un soporte electrónico es reconocida, respecto de cualquier persona, en el art. 3 de la Ley 19.799 y, respecto de los órganos del Estado, en el art. 6 y 7 de la misma Ley ${ }^{102}$. En este

100 Puppe (2013) núm. marg. 51 y s.

101 Binding (1904) p. 227 y ss., argumento para rechazar la teoría que fundamenta la norma de la falsedad documental en la protección de "formas de autenticidad"; en este sentido, también Puppe (1972) p. 173: "la declaración documentaria puede adquirir cualquier forma, en la medida en que sea perdurable”.

102 "Artículo $3^{\text {o. }}$ - Los actos y contratos otorgados o celebrados por personas naturales o jurídicas, suscritos por medio de firma electrónica, serán válidos de la misma manera y producirán los mismos efectos que los celebrados por escrito y en soporte de papel. Dichos actos y contratos se reputarán como escritos, en los casos en que la ley exija que los mismos consten de ese modo, y en todos aquellos casos en que la ley prevea consecuencias jurídicas cuando constan igualmente por escrito. Lo dispuesto en el inciso anterior no será aplicable a los actos o contratos otorgados o celebrados en los casos siguientes: a) Aquellos en que la ley exige una solemnidad que no sea susceptible de cumplirse mediante documento electrónico; b) Aquellos en que la ley requiera la concurrencia personal de alguna de las partes, y c) Aquellos relativos al derecho de familia. La firma electrónica, cualquiera sea su naturaleza, se mirará como firma manuscrita para todos los efectos legales, sin perjuicio de lo establecido en los artículos siguientes"; "Artículo 60.- Los órganos del Estado podrán ejecutar o realizar actos, celebrar contratos y expedir cualquier documento, dentro de su ámbito de competencia, suscribiéndolos por medio de firma electrónica. Se exceptúan aquellas actuaciones para las cuales la Constitución Política o la ley exija una solemnidad que no sea susceptible de cumplirse mediante documento electrónico, o requiera la concurrencia personal de la autoridad o funcionario que deba intervenir en ellas. Lo dispuesto en este Título no se aplicará a las empresas públicas creadas por ley, las que se regirán por las normas previstas para la emisión de documentos y firmas electrónicas por particulares"; "Artículo 7º.- Los actos, contratos y documentos de los órganos del Estado, suscritos mediante firma electrónica, serán válidos de la misma manera y producirán los mismos efectos que los expedidos por escrito y en soporte de papel. Con todo, para que tengan la calidad de instrumento público o surtan los efectos propios de este, deberán suscribirse mediante firma electrónica avanzada”. 
sentido, un documento dispositivo o testimonial vertido en soporte electrónico no coincide con la definición de "documento electrónico" acuñada en el art. 2 letra c) de la Ley citada: "documento electrónico: toda representación de un hecho, imagen o idea que sea creada, enviada, comunicada o recibida por medios electrónicos y almacenada de un modo idóneo para permitir su uso posterior". Es más restringido por su contenido, por lo tanto, se trata solo de una clase de "documento electrónico" en el amplio sentido acuñado en dicha disposición legislativa. Y es lógico que esto sea así. Porque esta disposición se enmarca en una ley que pretende introducir y regular el "documento electrónico" como un medio en general de las relaciones en el tráfico económico y jurídico, tanto entre particulares como en las relaciones de estos con el Estado. En cambio, el concepto de documento arriba analizado (supra 2.4.), que es más restringido por su contenido, es producto de una discusión entre doctrina y jurisprudencia desarrollada por más de un siglo, para los acotados efectos de delimitar el "objeto" de la conducta del delito de falsedad documental ${ }^{103}$.

\subsection{El injusto propio del Delito de Falsedad DOCUMENTAL: Un ENGAÑo SOBRE LA EXISTENCIA DE UN DOCUMENTO \\ Un fallo de la Corte de Apelaciones de Concepción, del 1 de diciembre de 1954, que se inscribe en una línea jurisprudencial de los Tribunales superiores de Justicia que desde antaño buscaba delimitar el alcance de los deberes del Notario en relación al otorgamiento}

103 En este sentido, Bacigalupo (2012) p. 4, en relación al concepto de documento introducido en el art. 26 del CP español; en la doctrina nacional, GARRIDo (2005) p. 196, advierte frente a la creación de "conceptos prejurídicos al margen de la normativa penal positiva, que pueden llevar a interpretar los tipos delictivos de manera extensiva (...)"; en este sentido, celebra la sabiduría del legislador penal en orden a restringir "el campo de lo delictivo solo a falsedades específicas en relación a los documentos públicos, pues no cualquiera alteración es falsedad, sino las que se llevan a cabo conforme al artículo 193, solo estas son constitutivas de delito" (p. 198), luego agrega que "el Código penal al aludir a las falsedades documentales en los artículos 193 y siguientes se refiere a determinados objetos de falsedad que describe taxativamente. Recogió nociones propias del Código civil para determinar lo que entiende por documento público y por documento privado (...)” (p. 199), la referencia de los tipos de falsedad "queda limitada a aquellos que conforme al Código civil (artículo 1699) tienen esa calidad, o sea, a aquellos que tienen sostén en papel y se encuentren escriturados" (p. 199), "siempre va implícito lo que en la época de promulgación de esos códigos se entendía por documentos, lo escrito por personas en soporte de papel" (p. 200); cierto, el legislador penal ha descrito taxativamente las modalidades de comisión de la falsedad en el art. 193, a las cuales remiten tanto el art. 194 como el art. 197 CP, sin embargo, no ha descrito ni lata ni taxativamente el "objeto" sobre el que recae dicha falsedad, por la simple razón de que la legislación penal no define el concepto de documento, ni público ni privado; tiene razón GARRIDO cuando advierte que el legislador penal recogió las nociones del Código civil, no obstante, esto implica solamente que, atendido el carácter accesorio del Derecho penal, la interpretación de las expresiones "documento público o auténtico" e "instrumento privado o mercantil" debe orientarse a las definiciones de los mismos contenidas en las normas prepenales, de la legislación civil, comercial y administrativa, no solamente del Código civil; en todo caso, el texto de esta legislación civil refiere a la escritura, pero no explícitamente al "soporte de papel"; este, se encuentra "implícito", pero no explícito en el Código civil; la Ley N. 19.799, cuyas normas comparten en igual dignidad el estatus de ser prepenales con las del CC, COT, CPC, etc., ha vuelto explícita la voluntad del legislador prepenal de valorar de modo equivalente el soporte de papel y el soporte electrónico; ergo, no se acuña un concepto "prejurídico", sino que simplemente se supeditan las valoraciones del legislador penal a las del legislador prepenal; y esta accesoriedad valorativa no conduce a una interpretación extensiva de la ley penal, pues, como se plasma en el texto principal, se suscribe un concepto más restrictivo que el amplio consagrado en el art. 2 letra c) de la Ley 19.799. 
de un documento público, recurre a la disposición del art. 1700 CC para delimitar las circunstancias fácticas que abarca la "fe pública documentaria", a la cual dicho funcionario se encuentra especialmente obligado ${ }^{104}$. Se trataba de un caso en que un ciudadano extranjero había mentido respecto de su nacionalidad ante un Oficial del Registro Civil, provocando así una inscripción de nacimiento como chileno por parte de este, para luego obtener una cédula de identidad en igual condición. La Corte arguye en su fallo que el deber del funcionario no abarca "la validez de las declaraciones" emitidas por las partes, sino que solo se extiende a las circunstancias incluidas en el art. 1700 CC, cuales son, el hecho de haberse otorgado un documento, por las partes que allí se expresan y en una fecha cierta. No obstante, a partir de esta constatación, la Corte extrae otra en el sentido de que "la falsedad documentaria en cuanto faltar a la verdad en la narración de hechos sustanciales solo puede alcanzar al funcionario" y no a las partes, cuya simulación solo constituye delito cuando se produce en perjuicio de terceros (art. 471 N. 2 CP) ${ }^{105}$. En otras palabras, la mentira por escrito, esto es, una declaración falsa vertida por escrito solo constituye delito cuando es realizada por el funcionario público, mas no por los particulares.

Sin embargo, a partir de la regla del art. 1700 CC no es posible llegar a tal conclusión, simplemente porque dicha norma solo delimita aquellos elementos constitutivos de un documento y no distingue entre las calidades que puede revestir el otorgante del mismo. Lo que quiere decir la Corte es que la declaración falsa, es decir, el engaño, cuando recae sobre circunstancias fácticas no abarcadas por el art. $1700 \mathrm{CC}$, por ejemplo, atributos o calidades de los declarantes, es punible cuando se realiza en perjuicio de terceros ${ }^{106}$. El criterio de distinción propuesto por la Corte, entonces, no radica en la existencia del engaño, sino que más bien en las circunstancias fácticas sobre las que este recae. Si uno se fija, las circunstancias que el art. 1700 CC declara relevantes para la configuración de un documento coinciden en buena medida con aquellas que se describen como elementos sobre los que recae la falsedad documental en los numerales 1 a 6 del art. 193 CP. En efecto, si uno lee atentamente cada una de las modalidades de comisión de la falsedad descritas en dicho

104 Contra Medina (1954); en este sentido, Contra Concha (1938), Oelckers y otro contra Rettig (1946).

105 Con nota aprobatoria de Grisolía (1956) p. 96 y ss., quien distingue diferentes grados de eficacia probatoria de las "declaraciones de ciencia", en base a la regla del art. 1700 en relación con la del art. 17 CC; a partir de la premisa que "el bien jurídico protegido por los delitos de falsedad documental es el valor probatorio del documento", colige que solo el funcionario está obligado como emisor de tales "declaraciones de ciencia" a un deber de veracidad, pero no los particulares, de tal modo que estos no pueden infringir "las normas" del art. 193 N.2, 3, 4 y 7 CP, sobre "falsedad ideológica"; no obstante, la argumentación de Grisolía sorprende por dos razones: (1), si lo protegido es el valor probatorio del documento, restringido a aquel respecto del cual el documento público "hace plena fe" (art. 1700), no se comprende por qué el mismo bien jurídico no podría ser lesionado también "desde afuera" por los particulares mediante una declaración falsa ante el funcionario; (2) la conclusión a la que llega Grisolía, en el sentido que, según el grado de la fuerza probatoria del documento público, los particulares no están obligados a la verdad, no es coherente con la premisa de la que parte, cual es el art. 1700 CC que dice exactamente lo contrario, esto es, que el instrumento público, además, hace plena fe de "la verdad de las declaraciones" en contra de los declarantes, esto es, de los particulares que concurren ante el funcionario a otorgarlo.

106 Carrara (1889) $\$$ 3662, llamaba esa clase de engaño como "falsedad ideológica”, la que, por las mismas razones, solo podía ser realizada por los particulares (!): "las partes pueden cometer falsedad ideológica, pero nunca puede cometerla el notario". 
tipo penal, puede notar que todas tienen un denominador común: se trata de elementos que reunidos configuran un documento. La existencia de un documento precisa la concurrencia de una firma o rúbrica (N. 1), supone la intervención de una persona, el otorgante (N. 2), que emite una declaración (N. 3), la cual puede consistir en una narración sobre hechos (N. 4), realizada en una fecha cierta (N. 5) y que se corporeiza en un texto que tiene un sentido (N. 6). En esta medida, el criterio diferenciador propuesto por la Corte es correcto. Porque, si uno revisa las circunstancias fácticas sobre las que recae el engaño en los delitos de "fraude patrimonial" tipificados principalmente en los artículos 467 y 468 $\mathrm{CP}$, es posible detectar otro denominador común. Así, en el delito de entrega "fraudulenta", el engaño recae sobre distintos atributos o calidades de la cosa entregada (art. 467 CP), mientras que las circunstancias sobre las que se engaña en el delito de estafa dicen relación todas con calidades o atributos de la persona del autor (art. 468 CP, v.gr.: "nombre fingido", "crédito supuesto"). El denominador común tanto a las calidades o propiedades de la cosa en el delito de entrega "fraudulenta" (art. 467) como a las calidades o atributos de la persona en el delito de estafa (art. 468) radica en que se trata siempre de circunstancias fácticas respecto de cuya existencia el autor engaña provocando un error en otro inversamente correlativo, esto es, la representación falsa de la presencia de dichas circunstancias en la realidad fáctica. En consecuencia, el delito de falsedad documental se distingue de la estafa no en la concurrencia de un engaño, es decir, una declaración falsa, una mentira. La falsedad documental también es un delito de engaño ${ }^{107}$. Se distingue de la estafa en los significados sobre los que recae el engaño. El injusto propio del delito de falsedad documental deriva del engaño sobre la circunstancia que una persona ha declarado algo determinado, el cual puede provocar en otro el error correlativo sobre la existencia de un documento ${ }^{108}$. O como dice recientemente Jakobs, no la declaración mentirosa, sino la documentación falsa constituye el injusto de la falsedad documental ${ }^{109}$.

Este injusto básico del delito de falsedad documental siempre ha estado castigado penalmente. Al menos respecto del testamento, que en el Derecho romano era un documento privado y cerrado, desde el año 81 a.C., y respecto de cualquier documento, cerrado o no, público o privado, desde mediados del siglo III d.C. ${ }^{110}$. El mismo injusto siguió estando castigado penalmente en la $7^{\text {a }}$ partida, título VII, de las Partidas del sabio Rey don

\footnotetext{
107 JAKOBS (2000) pp. 6 y ss., p. 18: "un engaño no es cualquiera manifestación de un hecho falso, sino que solo es tal en la medida en que infringe un derecho a la no ocurrencia de engaño, esto en plena correspondencia con el reconocimiento actualmente casi no discutido, que en ningún delito puede derivarse la antijuridicidad de la conducta a partir de la producción fáctica (dolosa) del resultado, que el carácter no permitido de la conducta deriva más bien solo del quiebre de un rol social garantizado como institución (según la teoría de la conducta típica como parte de la así llamada imputación objetiva”; en este sentido, también VARGAS (2011) pp. 186 y ss., 197 y ss.

108 Puppe (1972) p. 166, 173 y ss.; recientemente en este sentido, Freund (2010) núm. marg. 23, 40, 62, 142.

109 JAKOBS (2000) p. 25; una persona que otorga un documento se vuelve garante por el medio de prueba que introduce en el tráfico jurídico, tal como el fabricante de un producto que circula en el tráfico; desde ese instante asume frente a otros la garantía de asegurar la identidad del otorgante mediante un medio de prueba (p. 25 y s.; también p. 31: "quien crea un documento, está obligado a asegurarlo en el tráfico", p. 35: "quien crea un documento, es garante del medio de prueba”).

110 Rojas (2012) p. 548 y ss.
} 
Alonso el IX, recogida, mediante la Codificación penal europea del siglo XIX (art. 145 Code pénal de 1810 -art. 398 Código penal español de 1822- art. 226 Código penal español de 1848/1850) en el texto del art. $193 \mathrm{CP}^{111}$. Dicho injusto se encuentra abarcado por la descripción de la conducta típica contenida en el encabezado del art. $193 \mathrm{CP}$, al cual remite tanto el art. 194 como el art. 197 CP. Los numerales 1 a 7 del art. 193 CP describen simplemente diversas modalidades de comisión del injusto básico del delito de falsedad documental. Son sencillamente distintas formas de crear un documento falso, variados métodos conducentes a la falsedad documental. El engaño sobre cualquiera de los elementos abarcados por dichos numerales puede provocar en otro una representación falsa sobre la existencia de un documento. Por eso, no basta simplemente realizar cualquiera de estas modalidades de comisión. La conducta típica, el "verbo rector" se encuentra solo parcialmente descrito en dichos numerales. La configuración de la conducta prohibida exige que la realización de la modalidad de comisión lleve a la falsedad documental. La norma del art. 193 no prohíbe simplemente "contrahacer o fingir una firma" (N. 1), tampoco "suponer la intervención de una persona” (N. 2). Prohíbe la falsedad documental mediante el fingimiento de una firma o la suposición de la intervención de una persona en el otorgamiento de un documento.

La creación de un documento falso implica la negación del documento, es decir, el atributo "falso" importa lo contrario del documento ${ }^{112}$. En consecuencia, la falsificación ("falsedad material"), entendida como alteración o adulteración de un documento previamente existente, es solo una forma de la falsedad documental. Pues, todo aquel que falsifica un documento auténtico, esto es, modifica el contenido de la declaración documentaria, crea un documento falso ${ }^{113}$. Como lo esclarece Puppe: "es el engaño sobre la circunstancia de que una persona determinada debe dejar hacer valer contra sí la declaración fijada como su palabra, lo que el tráfico jurídico y el ordenamiento jurídico no pueden tolerar, porque pone en peligro un principio básico del ordenamiento jurídico: el de la atribuibilidad de las declaraciones emitidas en el tráfico jurídico a determinados sujetos de Derecho"114. En conclusión, la realización de las modalidades de "falsedad material" (v.gr.: N. 1, N. 6) o de "falsedad ideológica (v.gr:: N. 2, N. 3, N. 4), descritas en el art. 193 CP, fundamentan la punibilidad a este título solo cuando importan la realización del injusto de falsedad documental ${ }^{115}$.

\footnotetext{
111 Rojas (2012) p. 551 y ss. (nota 32), pp. 563 y ss. (nota 83).

112 Binding (1904) p. 230.

113 Puppe (2013) núm. marg. 84, respecto de la modalidad del "Verfälschen" incluida por este tipo del Código penal alemán a renglón seguido del "Fälschen", que entonces tilda de redundante ("überflüssig").

114 Puppe (1972) p. 178.

115 Que correlativamente vulnera un derecho negativo a la verdad, JAKOBS (2000) p. 11 y ss., dice: "Disponibilidad e información" (destacado original), se trata de la protección de un estado de información que es presupuesto de la libertad de disposición del sujeto, sin el cual este no podría participar en el tráfico jurídico, tal como por ejemplo, un soldado con un arsenal de armas que no sabe dónde están sus enemigos o un filántropo lleno de recursos que no sabe dónde están sus necesitados; pero, en la falsedad documental, no se trata de una garantía de la información correcta, sino solo del derecho que tiene la persona a que su esfera de información no se vea diezmada.
} 
Este injusto básico del delito de falsedad documental, sin embargo, no agota todo el contenido de injusto del tipo de los arts. 193 y 194 CP. En la medida en que un documento puede contener una "narración sobre hechos", entonces esta también puede ser falsa en el sentido de no correspondencia con estos últimos (art. 193 N. 4 CP). Esta modalidad de falsedad abre la posibilidad de realización de un injusto de falsedad documental en un sentido distinto del previamente analizado. No se trata aquí de la creación de un documento falso en el sentido de un no documento. Existe un documento, pero su narración es falsa por no corresponderse con los hechos. La narración sobre hechos presupone una observación. Por lo tanto, esta modalidad de falsedad se restringe al documento testimonial, porque solo este da cuenta de la observación de un hecho jurídicamente relevante. Solo respecto de la afirmación contenida en un documento testimonial es posible formular un juicio de verdad como correspondencia o de falsedad como no correspondencia con el hecho observado. Además, las normas jurídicas prepenales garantizan la corrección de afirmaciones contenidas solamente en documentos públicos, esto es, otorgados por o ante un funcionario público ${ }^{116}$. Por lo tanto, esta modalidad de falsedad solo puede realizarse en un documento testimonial público. Esto implica entonces que el tipo de los arts. 193 y 194 CP describe un doble injusto: el injusto básico de falsedad documental como creación de un no documento y, además, el injusto de falsedad como creación de un documento que fija una narración falsa sobre un hecho jurídicamente relevante. En cambio, el injusto básico de falsedad documental agota todo el contenido de injusto del tipo del art. 197 CP. La norma subyacente a este tipo prohíbe solamente la creación de un documento, dispositivo o testimonial, privado falso en el sentido de inexistente.

\section{CONCLUSIONES}

1. La forma en que la dogmática tradicionalmente se aproxima a la materia, le impide ver la existencia de un injusto básico del delito de falsedad documental. Esta aproximación tradicional es inducida por la técnica de legislación penal adoptada en los arts. 193 y ss. del Código penal, que coloca en primer plano un tipo (el art. 193) de falsedad en documento público basado en el concepto de fe pública. La fe pública, a su turno, se relaciona con un concepto de verdad como correspondencia entre narración y hecho, cuyo deber de protección alcanzaría solamente al funcionario público.

2. La teoría del bien jurídico ha servido para perpetuar esta forma de aproximarse a la materia, recodificando el concepto de fe pública en el lenguaje del "bien jurídico". La doctrina dedica ingentes esfuerzos para alcanzar una explicación razonable del bien jurídico protegido por la norma y un escuálido análisis del concepto de documento. Se preocupa antes que nada de identificar el bien jurídico protegido -la fe pública- y el sujeto apto para lesionarlo -el funcionario público-, pero en ese intento soslaya el significado de la conduc-

\footnotetext{
116 Puppe (2009) p. 8: "El deber de verdad del notario documentador se extiende a determinados antecedentes en el documento, no porque estos gocen de fe pública y fuerza probatoria para y contra cualquiera, sino que estos antecedentes gozan de fe pública, porque el deber de verdad del notario se extiende a ellos".
} 
ta realizada por el sujeto. El significado antijurídico de la conducta se encuentra descrito ya en el encabezado del tipo del art. 193 con la frase "cometer falsedad".

3. La presente investigación constituye un intento por esclarecer el significado solamente de esta frase: "cometer falsedad en un documento". Busca responder solamente a la pregunta: ¿qué significa cometer falsedad documental? Esta pregunta no puede responderse sin aproximarse al concepto de documento. Este concepto ha sido desarrollado de forma inigualable por la jurisprudencia y la doctrina alemana. Ya en la jurisprudencia del Reichsgericht a fines del siglo XIX se alcanza un nivel admirable de profundidad y diferenciación en la elaboración dogmática del concepto de documento (véase supra notas 31 y 71). Esta concentración en la pregunta por el documento y este esfuerzo de profundidad conceptual tienen su explicación en una distinta técnica de legislación penal, que antepone en la sistemática de los delitos de falsedad documental un tipo que describe el injusto básico de falsedad documental ( $\$ 267$ StGB), a partir de la frase "el que hiciere un documento inauténtico”. El precedente histórico del Código penal alemán vigente, el Reichsstrafgesetzbuch de 1871 explicitaba que ese documento, que se otorga falsamente, podía ser público o privado. Por eso, la jurisprudencia y doctrina alemana analizan primeramente el concepto de documento como tal. El carácter de público o privado solo se adiciona al concepto de documento. Porque la conducta prohibida descrita en el tipo base del sistema consiste simplemente en crear un documento falso, público o privado.

4. La tesis que se sostiene en este trabajo radica en que la descripción de la conducta prohibida incluida en el encabezado del tipo del art. 193 - "cometer falsedad"-, al cual remiten tanto el tipo del art. 194 como el del art. 197, abarca el mismo injusto básico del delito de falsedad documental descrito en el tipo del $\$ 267$ StGB. Esto es: crear o hacer un documento falso, inexistente, público o privado. Por ende, la norma subyacente al tipo del art. 193 CP prohíbe al empleado público crear un documento público falso, la implícita en el tipo del art. 194 extiende esta misma prohibición al particular y aquella norma subyacente al tipo del art. 197 prohíbe a cualquier persona crear un documento privado falso. La diferencia proviene únicamente de la modalidad de comisión descrita en el art. $193 \mathrm{~N}$. 4 CP que alude explícitamente a la falsedad como discrepancia entre narración y hecho y, por ende, presupone un concepto de verdad como correspondencia. Esto implica que el tipo del art. 193 y, por extensión, también el tipo del art. 194 CP, abarcan otro injusto de la falsedad documental, entendido como creación de un documento existente, pero cuyo contenido es falso en el sentido de no correspondencia con el hecho. Este otro injusto del delito abarcado por la descripción contenida en ambos tipos penales se restringe, sin embargo, conceptualmente a una clase de documentos: el documento testimonial y público. Solo respecto del documento testimonial público es posible realizar este otro injusto del delito de falsedad documental, por un funcionario público (art. 193 N. 4) o por un particular (art. 194). En el Código penal alemán, este otro injusto lleva otro nombre (“falsche Beurkundung": falsa documentación) y se encuentra tipificado de modo separado en los $\$ \$ 271$ (respecto del particular) y 348 (respecto del funcionario público). Se trata simplemente de otra técnica de legislación penal, más diferenciada. La técnica legislativa adoptada por el Código penal chileno de 1874 es menos diferenciada, porque deriva históricamente del Code pénal de 1810, y, por eso, confunde e incluye en un mismo tipo penal, el del art. 
193, dos injustos diferentes relativos al documento, esto es, un doble injusto: (1) el injusto básico de la falsedad documental entendido como creación de un documento falso en el sentido de inexistente y (2) el injusto de la falsedad documental comprendido en el sentido de un documento existente, pero cuyo testimonio sobre hechos falta a la verdad como correspondencia.

5. Una técnica legislativa poco depurada, menos diferenciada, es solamente una opción del legislador histórico. No implica que el texto de la ley penal no abarque ambos injustos del delito reseñados. El comprensible esfuerzo que ha destinado la doctrina y jurisprudencia de raigambre latina a lo largo de más de un siglo de álgida discusión para no hacer responder penalmente a un particular por una simple "mentira por escrito" ("delito de falsedad ideológica"), ha relegado al más profundo olvido la existencia del injusto básico de falsedad documental. Sentido y fin de este trabajo consiste solamente en rescatar del olvido y traer nuevamente a luz este injusto básico del delito de falsedad documental.

\section{BIBLIOGRAFÍA CITADA}

Actas de las sesiones de la Comisión Redactora del Código penal chileno, 1873.

Bacigalupo, Enrique (2007): Falsedad documental, estafa y administración desleal (Barcelona, Editorial Marcial Pons).

Bacigalupo, Enrique (2002): "Documentos electrónicos y delitos de falsedad documental”, Revista Electrónica de Ciencia Penal y Criminología N. 04. Disponible en:<http://criminet.ugr.es/recpc/recpc_04-12.pdf:>: pp. 1-17.

Binding, Karl (1904): Lehrbuch des Gemeinen Deutschen Strafrechts, Besonderer Teil, t. II (Leipzig, Editorial von Wilhelm Engelmann, segunda edición).

Boldova, Miguel Angel (2000): Estudio del bien juridico protegido en las falsedades documentales (Granada, Editorial Comares).

Carrara, Francesco (1889): Programa de Derecho criminal, Parte Especial, vol. VII (Bogotá, Editorial Temis, quinta edición).

Cousiño, Luis (1944): "La falsificación de instrumento privado", Revista de Ciencias Penales, tomo VII: pp. 5-23, pp. 99-206.

ERB, Volker (2011): “Die Unvereinbarkeit der „Zufallsurkunde“ mit einem dogmatisch konsistenten Urkundenbegriff”, en Paeffgen et al. (edit.), Festschrift für Ingeborg Puppe zum 70. Geburtstag (Berlin, Duncker \& Humblot): pp. 1107-1118.

Etcheberry, Alfredo (1961a): "El objeto jurídico en los delitos de falsedad documental", Revista de Ciencias Penales, tomo XX: pp. 33-66.

Etcheberry, Alfredo (1961b): "El objeto material del delito de falsedad documental: documentos y sus clases", Revista de Ciencias penales, tomo XX: pp. 219-240.

Etcheberry, Alfredo (1997): Derecho penal, Parte Especial, tomo IV (Santiago, Editorial Jurídica, tercera edición).

Etcheberry, Alfredo (2002): El Derecho penal en la jurisprudencia, Parte Especial, tomo III (Santiago, Editorial Jurídica).

FERnÁndeZ, Pedro Javier (1899): Código penal (Santiago, segunda edición). 
Frank, Reinhard (1908): Das Strafgesetzbuch für das Deutsche Reich nebst dem Einführungsgesetze (Tübingen, Editorial Mohr Siebeck, quinta a séptima edición).

Freund, Georg (2010): Urkundenstraftaten (Heidelberg, Editorial Springer, segunda edición).

García Cantizano, María del Carmen (1997): Falsedades documentales (Valencia, Editorial Tirant lo Blanch).

Garrido, Mario (2005): "El documento, en especial el público o auténtico, en el ámbito penal”, en Revista de Derecho de la Pontificia Universidad Católica de Valparaíso, tomo XXVI, Semestre I: pp. 195-200.

Garrido, Mario (2008): Derecho penal, tomo IV, parte especial (Santiago, Editorial Jurídica, cuarta edición).

Grisolía, Francisco (1956): Nota en Revista de Ciencias Penales, tomo XV: pp. 95-98.

Guzmán Dalbora, José Luis (2007): Estudios y defensas penales (Santiago, Editorial LexisNexis, segunda edición).

JAKOBS, Günther (2000): Urkundenfälschung, Revision eines Täuschungsdelikts (Köln, Editorial Carl Heymanns).

JAKOBS, Günther (2007): „Bemerkungen zur Urkundenfälschung“ en Hettinger et al. (edit.), Festschrift für Wilfried Küper zum 70. Geburtstag (Heidelberg, Editorial Müller): pp. 225-236.

KienaPfel, Diethelm (1967): Urkunden im Strafrecht (Frankfurt a.M., Editorial Klostermann).

Kohlrausch, Eduard (1929): “Urkundenverbrechen”, en Stier-Somlo y Elfter (edit.) Handwörterbuch der Rechtswissenschaft, tomo VI (Berlin/Leipzig, Editorial Walter de Gruyter): pp. 334-338.

LAMPE, Ernst-Joachim (1957): Fälschung von Gesamturkunden und von zusammengesetzten Urkunden (Mainz).

Londoño, Fernando (2010): "Comentario a la STOP de Calama de 30 de septiembre de 2008 (RUC: 0410000245-6)”, en Doctrina y Jurisprudencia Penal, N. 3, Fraudes especiales (Editorial AbeledoPerrot/LegalPublishing): pp. 55-67.

LuHMann, Niklas (1993): Das Recht der Gesellschaft (Frankfurt, Editorial Suhrkamp).

Merkel, Adolf (1889): Lehrbuch des Deutschen Strafrechts (Stuttgart, Editorial von Ferdinand Ente).

Ortiz, Pedro (1944): "La falsificación de instrumento privado", Revista de Ciencias Penales, tomo VII: pp. 207-214.

Peña, Federico (1954): "Observaciones acerca del artículo 27 de la Ley 4.808 sobre Registro Civil, de 31 de enero de 1930", Revista de Derecho y Jurisprudencia: pp. 53-59.

Puppe, Ingeborg (1972): Die Fälschung technischer Aufzeichnungen (Berlin, Editorial Duncker \& Humblot).

Puppe, Ingeborg (2009): “Die Wahrheitspflicht des Notars”, en Kindhäuser (edit.), Strafrechtliche Aspekte notarieller Tätigkeit (Baden-Baden, Editorial Nomos).

Puppe, Ingeborg (2013): „Comentario al $\$ 267$ StGB“, en Kindhäuser et al. (edit.), Nomos Kommentar (Baden-Baden, Editorial Nomos, cuarta edición). 
Politoff, Sergio et al. (2007): Lecciones de Derecho penal chileno, parte especial (Santiago, Editorial Jurídica, segunda edición).

RHEINECK, Renate (1979): Fälschungsbegriff und Geistigkeitstheorie (Berlin, Editorial Duncker \& Humblot).

Rodríguez Collao, Luis y Vera, Jaime (2004): "El bien jurídico protegido en los delitos de falsedad", Revista de Derecho, Universidad Católica de Temuco, año 5, N. 5: pp. 113 135.

Rojas, Luis Emilio (2012): "Historia dogmática de la falsedad documental", Revista de Derecho de la Pontificia Universidad Católica de Valparaiso, vol. 39, № 2: pp. 545-583.

Samson, Erich (1968): Urkunde und Beweiszeichen (Baden-Baden, Editorial Nomos).

SAnHuEZA, Juana (1991): "La falsedad ideológica en el informe de alcoholemia. Comentarios a una sentencia”, Revista de Derecho, Universidad de Concepción, N. 189: pp. $35-40$.

Saussure, Ferdinand de (1965): Cours de linguistique générale, texto establecido por Bally et al. (Paris, Editorial Payot).

Soler, Sebastián (1967): Derecho Penal Argentino, parte especial, tomo V (Buenos Aires, Editora Argentina).

SteinMETZ, Bernd (1991): Der Echtheitsbegriff im Tatbestand der Urkundenfälschung (\$ 267 $S t G B)$ (Berlin, Editorial Duncker \& Humblot).

VARGas, Tatiana (2011): "Daño del engaño en documentos privados. Aproximación al perjuicio en la falsificación de instrumentos privados", Revista de Derecho de Valdivia, vol. XXIV, No 2: pp. 179-204.

VARGas, Tatiana (2013): Falsificación de instrumento privado. Un estudio práctico entre la falsificación y la estafa (Santiago, Editorial LegalPublishing / ThomsonReuters).

Villacampa, Carolina (1999): La falsedad documental: análisis juridico penal (Barcelona, Editorial Cedecs).

\section{NORMAS CITADAS}

Ley de Tránsito, D.F.L. N. 1, del 29 de octubre de 2009, fija texto refundido, coordinado y sistematizado de la Ley de Tránsito.

LEY N. 19.545 del 9 de febrero 1998, crea un sistema de certificación oficial de conformidad de exportaciones.

Ley de Pesca, N. 19.713 del 25 de enero de 2001, establece como medida de administración el límite máximo de captura por armador a las principales pesquerías industriales nacionales y la regularización del registro pesquero artesanal.

Ley N. 19.799 del 12 de abril de 2002, sobre documentos electrónicos, firma electrónica y servicios de certificación de dicha firma.

\section{JURISPRUDENCIA CITADA}

Contra Duque (1930): Corte Suprema, 8 de enero de 1930 (casación en el fondo), Gaceta de Tribunales, tomo $1^{\text {er }}$ semestre, sentencia $N^{\circ} 42$, pp. 204 y ss. 
Contra Concha (1938): Corte Suprema, 17 de agosto de 1938 (casación en el fondo), Gaceta de Tribunales, tomo $2^{\circ}$ semestre de 1938, sentencia $\mathrm{N}^{\circ} 42$, pp. 211 y ss.

Oelckers y otro contra Rettig (1946): Corte Suprema, 18 de octubre de 1946 (casación en el fondo), Gaceta de Tribunales, tomo 2 semestre de 1946, sentencia № 28, pp. 163 y ss.

Banco Central de Chile contra Becerra (1947): Corte Suprema, 30 de septiembre de 1947 (casación en el fondo), Gaceta de los Tribunales, tomo $2^{\circ}$ semestre, sentencia $\mathrm{N}^{\circ} 45$, pp. 244 y ss.

Contra Toriello (1950): Corte Suprema, 31 de mayo de 1950 (casación en el fondo), Gaceta de Tribunales, tomo 1 semestre, sentencia $N^{\circ} 53$, pp. 288 y ss.

Contra Matus (1950): Corte Suprema, 22 de agosto de 1950 (recurso de queja), Gaceta de Tribunales, tomo 2 semestre, sentencia $\mathrm{N}^{\circ} 59$, pp. 391 y ss.

Contra Arzola (2010): Corte Suprema, 9 de diciembre del 2010 (casación en el fondo), Rol $\mathrm{N}^{\circ} 3481-2009$.

Contra Fernández (2008): Corte de Apelaciones de Antofagasta, 27 de junio del 2008 (recurso de nulidad), Rol №. 117-2008.

Contra Medina (1954): Corte de Apelaciones de Concepción, 1 de diciembre de 1954 (consulta), Revista de Derecho y Jurisprudencia y Gaceta de Tribunales, tomo noviembre y diciembre de 1954, No 9 y 10, pp. 258 y ss.

Bavestrello con Dall' Orso (1936): Corte de Apelaciones de Valparaíso, 30 de noviembre de 1936 (apelación), Gaceta de Tribunales, tomo 1 semestre de 1941, sentencia N 44, pp. 249 y ss.

Contra Minder (1943): Corte de Apelaciones de Santiago, 13 agosto de 1943 (apelación), Gaceta de Tribunales, tomo 2 semestre de 1943, sentencia No 52, pp. 228 y ss.

Contra Tejías (1955): Corte de Apelaciones de Santiago, 21 de junio de 1955 (apelación), Revista de Derecho y Jurisprudencia y Gaceta de Tribunales, tomo enero a abril de 1956, $\mathrm{N}^{\circ} 1$ y 2, pp. 9 y ss.

Contra Olguin (1955): Corte de Apelaciones de Santiago, 10 de noviembre de 1955 (casación en la forma y apelación subsidiaria), Revista de Derecho y Jurisprudencia y Gaceta de Tribunales, tomo septiembre-octubre de $1956, \mathrm{~N}^{\circ} 7$ y 8 , pp. 113 y ss.

Contra Quinteros (1959): Corte de Apelaciones de Santiago, 19 de septiembre de 1959 (consulta), Revista de Derecho y Jurisprudencia y Gaceta de los Tribunales, tomo septiembre-octubre 1959, No 7 y 8 , pp. 247 y ss.

RGSt. 13, 71.

RGSt. 17, 103.

BGHSt. 5, 75. 